\title{
The Metaphysics of Causal Intervention
}

\author{
Michael S. Moore $\dagger$
}

\section{INTRODUCTION}

This is the third in a series of articles on causation in the law. In the first article, ${ }^{1}$ I sought to lay out the various legal doctrines and legal theories of causation; in the second, I sought to show how the law of torts and the law of crimes presuppose a concept of causation consisting of ten characteristics. ${ }^{2}$ One of those characteristics-the one on which I shall focus in this Essay-goes under various names in the law. It has been called the doctrine of "isolating causes," "superseding causes," "intervening causes," "extraneous causes," or in the law-Latin favored in the nineteenth century, novus causa interveniens or novus actus interveniens. As I described the presupposition of this doctrine earlier:

Causal chains may be sharply broken and not inerely gradually diminished. The intervening causes responsible for such breaks may be of three kinds: deliberate human interventions, freakishly abnormal natural events, and subsequent preemptive causes. Although there inay be liability for failing to prevent certain such interventions, or for aiding such interventions in doing their causal work, there is no causal relationship across such intervening events at the basis of such hability. ${ }^{3}$

Considerable exegetical work is required to derive this characteristic cleanly from the law we have. In particular, one has to reallocate liability for omissions, for provision of opportunities to third-party wrongdoers, for aiding and encouraging third-party wrongdoers, for aiding forces of nature, away froin their supposed causal bases, into noncausal forms of liability. Having spent considerable time in one of the earlier articles doing this

Copyright $\odot 2000$ Michael S. Moore.

$\dagger \quad$ Leon Meltzer Professor of Law, Professor of Philosophy, Co-Director, Institute for Law and Philosophy, University of Pennsylvania.

1. See Michael S. Moore, Causation, in 1 Encyclopedia of Crime and Justice (Joshua Dressler et al. eds., rev. ed. forthcoming 2000).

2. See Michael S. Moore, Causation and Responsibility, Soc. PHLL. \& PoL'y, Summer 1999, at 1.

3. Id. at 44 . 
exegetical work, ${ }^{4}$ I shall not repeat or even summarize here the reasons for such reallocation. Rather, I shall here assume such reallocation to be justified so that we can say simply and without exception: Certain interventions by third-party actors or by nature break the causal chains that would otherwise have existed between some defendant's action and some harm to another.

My present inquiry is to see what metaphysical sense we can make of this interveming-cause doctrine of the law. How can causation be a relation that breaks off suddenly with the intervention of some new force or agency, rather than petering out gradually over space and time? I say "metaphysical sense" advisedly, because my inquiry is not into the policy reasons that may or may not support the construction of a legal doctrine of intervening causation. At one time, for example, lawyers constructed a notion of interveming causation in the form of the last-wrongdoer rule. ${ }^{5}$ The doctrine stated that the wrongdoer closest in time to the harm was alone liable for having caused that harm; the policy justification was that neither tort plaintiffs nor the state (in criminal prosecutions) needed more than one guilty party per wrong. All prior wrongs were "cut off" by the intervention of the last wrongdoer. Such a construction makes no bones about its fictional, constructed character; such intervening-cause doctrine seeks no support from any underlying metaphysics of causation.

By contrast, my inquiry is avowedly metaphysical. The question is whether the intervening-cause notions of the law can be based on a prelegal notion of causation, one that provides a solid grounding for the sharp breaks in causal chains so marked by the law. In such a case, the doctrines of intervening causation would not be bereft of policy justification-for all law, on my view of it, must be based on "policy," that is, on good reasons. But on the metaphysical view of intervening-causation doctrines, the policy justification would be two steps removed. The policy would be to attach legal liability (in the form of tort damages and criminal punishments) to morally blameworthy actions. It is morality, not legal policy, that tells us that actions that cause harm are more blameworthy than those that merely atteinpt or risk such harm. It is metaphysics, not legal policy, that tells us when an action causes a certain harm. Such a desert-oriented policy behind the law of torts and the law of crimes thus justifies not looking to policy in seeking the meaning of causation in general and of intervening causation in particular. A legal doctrine of intervening causation is justified-on this corrective justice view of torts and retributive justice view of crimes-if it corresponds to a prelegal, metaphysical notion of intervening causation.

4. See id. at 17-24,31-43.

5. The last-wrongdoer rule is discussed in Laurence Eldredge, Culpable Intervention as Superseding Cause, 86 U. PA. L. REv. 121 (1938). 
I realize that to many post-Legal Realist legal academicians the foregoing description of my enterprise makes them wonder whether they haven't landed on Mars. For the Legal Realists achieved some of their most resounding victories over their enemies, the "formalists," on the battlegrounds of intervening causation. ${ }^{6}$ They convinced subsequent generations of legal scholars that all proximate cause doctrines, including those of intervening causation, were merely misleading metaphors for underlying policies, and that such policies were better brought into the light of day instead of being obscured in mysterious but ultimately empty metaphors of forces being spent, causes intervening, and the like.

Yet my intellectual forebears here are not simply those pre-Legal Realist scholars of causation, such as Joseph Beale, ${ }^{7}$ Francis Bohlen, ${ }^{8}$ Jeremiah Smith, ${ }^{9}$ Henry Terry, ${ }^{10}$ James McLaughlin, ${ }^{11}$ and others. ${ }^{12}$ Most notably, I have been anticipated in my post-Legal Realist rescue project by the significant work on intervening causation done by Herbert Hart and Tony Honoré between 1956 and $1995 .{ }^{13}$ For they too sought to rediscover a prelegal notion of causation that made metaphysical sense of the law's doctrines of proximate (and intervening) causation. In my explication of those doctrines in the next Part, I shall thus rely heavily on their work as well as that of the pre-Legal Realist scholars.

My other intellectual forebear here is Sandy Kadish. ${ }^{14}$ For Dean Kadish $^{15}$ too felt the appeal of the Hart and Honoré rescue project for

6. See, e.g., Henry W. Edgarton, Legal Cause, 72 U. PA. L. REv. 211, 343 (1924); Leon Green, Are There Dependable Rules of Causation?, 77 U. PA. L. Rev. 601 (1929).

7. See Joseph Beale, Recovery for Consequence of an Act, 9 HaRv. L. REv. 80 (1895) [hereinafter Beale, Recovery]; Joseph Beale, The Proximate Consequence of an Act, $33 \mathrm{HARv}$. L. REv. 633 (1920) [hereinafter Beale, Proximate Consequence].

8. See Francis $\mathrm{H}$. Bohlen, The Probable or the Natural Consequence as the Test of Liability in Negligence, 49 AM. L. REG. 79, 148 (1901).

9. See Jeremiah Smith, Legal Cause in Actions of Tort, 25 HARv. L. REv. 103, 223, 303 (1911).

10. See Henry T. Terry, Proximate Consequences in the Law of Torts, 28 HARv. L. Rev. 10 (1915).

11. See James Angell McLaughlin, Proximate Cause, 39 HARv. L. Rev. 149 (1925).

12. See Norris J. Burke, Rules of Legal Cause in Negligence Cases, 15 CaLIF. L. Rev. 1 (1926); Charles E. Carpenter, Proximate Cause (pts. 1-3), 14 S. Cal. L. Rev. 1, 115, 416 (1940), 15 S. Cal. L. Rev. 187, 304, 427 (1941), 16 S. CAL. L. Rev. 1, 61, 275 (1943) [hereinafter Carpenter, Proximate Cause]; Charles E. Carpenter, Workable Rules for Determining Proximate Cause, 20 CALIF. L. REv. 229, 396, 471 (1932) [hereinafter Carpenter, Workable Rules]; Eldredge, supra note 5; Albert Levitt, Cause, Legal Cause and Proximate Cause, 21 Mich. L. Rev. 34, 160 (1922); Andrew C. McIntosh, Intervening Criminal Act as Breaking Causal Chain, LAw Nores, Sept. 1931, at 109; Victor I. Minahan, The Doctrine of Intervening Cause in the Law of Negligence, 4 MARQ. L. Rev. 75 (19191920).

13. See H.L.A. HaRt \& A.M. Honore, Causation IN the LaW (1959) [hereinafter HaRT \& honoré, Causation (ist ed.)F H.L.A. Hart \& Tony Honoré, Causation in the Law (2d ed. 1985) [hereinafter HART \& HonORE, CAusation (2d ed.)]; H.L.A. Hart \& A.M. Honoré, Causation in the Law, 72 L.Q. REv. 58, 260, 398 (1956); Tony Honore, Necessary and Sufficient Conditions in Tort Law, in Philosophical Foundations of ToRt LaW (David G. Owen ed., 1995).

14. See Sanford Kadish, Causation and Complicity: A Study in the Interpretation of Doctrine, 73 Calif. L. Rev. 323 (1985), reprinted in Sanford Kadish, Blame and Punishment (1987) 
causation in the law and has added his own considerable talents to furthering that project. In particular, Kadish saw more clearly than Hart and Honore how embedded in criminal law doctrine is the notion of intervening causation. As Kadish has pointed out in great detail, the doctrine forms a watershed divide in criminal law, separating liability as a principal from liability as an accomplice. Indeed, as Kadish saw, it is precisely because of the nature of our intervening-cause doctrine that we impose a secondary liability for those actors whose wrongful conduct makes possible the later wrongdoings of others. Accomplice liability fits like soft clay around the contours of principal liability, contours set by the doctrines of intervening causation.

Kadish took this doctrinal insight in two directions. First, he sought to ground the doctrines of intervening causation in metaphysics, specifically, in a libertarian metaphysics of free will. Although he himself did not endorse or reject such a metaphysics, he sought to show how such a metaphysical view was plausible, accepted by many, and made metaphysical sense of the doctrines of intervening causation. Second, Kadish sought to ameliorate the Model Penal Code's rejection of intervening causation, by adding language to section 2.03 of that Code putting the concept back in. ${ }^{16}$ Although California did not adopt Kadish's proposed language, other states have done so. ${ }^{17}$

By showing in detail how the notion of intervening causation is embedded in the basic structure of the criminal law, by deepening the notion's metaphysical groundings, and by extending the notion into hitherto alien quarters, Sandy Kadish has made my present project possible. It is thus a pleasure, and a fitting tribute, to include my own musings on this topic in this symposium in his honor.

[hereinafter Kadish, Causation and Complicity]; Sanford Kadish, $A$ Theory of Complicity, in Issues IN Contemporary Legal Philosophy: The Influence of H.L.A. Hart 287 (Ruth Gavison ed., 1987) [hereinafter Kadish, Theory of Complicity].

15. Although no longer Dean of Boalt Hall, Sandy is Dean of American criminal lawyers for many of us.

16. Model Penal Code subsections 2.03(2)(b) and (3)(b) qualify its general harm within the risk test by requiring that a harm not be "too remote or accidental in its occurrence to have a [justl bearing on the actor's liability or on the gravity of his offense." Kadish's proposed revision of this language was to add "or dependent on another's volitional act" after "occurrence." CALIFORNIA LegislatuRE Joint Comm. for the Revision of the Penal Code, Penal Code Revision Project § 408(i)(a)(ii) (Tentative Draft No. 2, 1968). Califomia did not adopt this language because, as the late John Kaplan used to say, Kaplan and Kadish had also liberalized the Penal Code's marijuana provisions.

17. See the citations in Criminal Law and ITs Processes $581 \mathrm{n} .2$ (Sanford H. Kadish \& Stephen J. Schulhofer eds., 6th ed. 1995). 


\section{The Legal Doctrines of Intervening Causation}

\section{A. The Role of Intervening Cause}

Within the Causal Requirements of the Law

In this Part, I undertake the description of what it is that needs justification in metaphysics, namely, the legal doctrines of intervening causation. Mostly I shall describe the content of such doctrines. Preliminarily, however, we need to assay the place of such doctrines in the larger scheme of things.

Least controversially, intervening-cause problems are a subset of the larger problems of proximate causation. ${ }^{18}$ On this view, causation in tort and criminal law is divided into two separate requirements, causation-infaet and proximate causation. Intervening-cause doctrines are assigned exclusively to the second of these requirements. They are something of a sideshow even here. The main show has to do with remoteness issues, couched in terms of spacio-temporal proximity, substantiality of causal contribution, foreseeability, and the like. Intervening-cause doctrines are needed only in that subset of cases where something unusual intervenes between defendant's action and his victim's harm. In all other cases, proximate cause issues are adjudicated without reference to such doctrines.

A more controversial role for intervening-cause doctrines is to see thein as occupying the entire logical space of proximate causation. ${ }^{19} \mathrm{~A}$ proximate cause is a "direct cause," and a direct cause is any cause-in-fact of the harm where no other cause has intervened. Such a direct-cause test of proximate causation relies on the notion of intervening cause to fill out entirely the legal requirement of proximate cause. On this view, simple reinoteness is irrelevant; what counts is the intervention of those special events we call intervening causes.

The most expansive view of nitervening causation is one fairly attributable to Hart and Honoré..$^{20}$ On this view, the concepts involved in elucidating the notion of intervening cause are the very same concepts that give the meaning of causation generally. This view of intervening causation

18. This is the view of Sandy Kadish, among others. See particularly his proposed revision of Model Penal Code $\$ 2.03$, which makes intervening causation only a kind of per se rule about freakishness of consequences. For other examples, see Meir Dan-Cohen, Causation, in I ENCYClopedia of CRIME AND Justice 162, 163 (Sanford Kadish ed., 1983), who regards interveningcause tests as supplements to more general tests of proximity and foreseeability. See also Bohlen, supra note 8; Carpenter, Proximate Cause, supra note 12; Carpenter, Workable Rules, supra note 12.

19. This is the view of Terry, see Terry, supra note 10, and (implicitly, as McLaughlin argues), of Beale, see Beale, Recovery, supra note 7; Beale, Proximate Consequence, supra note 7.

20. Jointly authored works always pose some special problems of interpretation. I am more confident that the view in the text was that of Herbert Hart than I am that it was fully shared by Tony Honoré. As I explore below, Hart believed in paradigms as a mode of giving the meaning of expressions in natural languages, whereas Honore perhaps always held the view that one could define a separable notion of cause-in-fact in terms of necessary and sufficient conditions. 
thus has the idea occupying the entire field of causation, not just some separable part of it such as proximate causation. The criteria by which one ascertains what is or is not an intervening cause are the very same criteria by which one decides what a cause is at all. There is thus no separable, preliminary step of isolating "causes-in-fact." Rather, we use certain paradigms to ascertain what is the cause of a certain event, albeit we use them twice: What is a cause must both fit such paradigms and not be succeeded in time by some other event that also fits such paradigms.

For our present purposes we need not determine initially which of these roles for intervening causation requirements is correct. Such a role falls out naturally enough from the content of the doctrines of intervening causation and from the metaphysical rationale behind such content. We should thus turn to that content itself.

\section{B. The Content of the Intervening-Cause Doctrines}

It has been customary in the literature of intervening causation to divide intervening causes into two kinds, those consisting of extraordinary natural events and those consisting of wrongful human actions. ${ }^{21}$ Although there are good reasons to honor this traditional division, and we shall do so later, initially it is helpful to regard intervening causes as a unitary phenomenon and to seek the general properties shared (or thought to be shared) by all species of the genus. I consider several such general properties below.

\section{The Temporal Condition: Intervening Causes Must Intervene Between Defendant's Act and the Harm}

The most basic feature of an intervening cause is that it must intervene. This will obviously eliminate events occurring after the victim's harm from the category of intervening causes (or, indeed, causes of any kind, causation not working backwards through time). Less obviously, this rule also precludes events that predate the defendant's action and states that are in existence at the time the defendant acts, from being intervening causes. ${ }^{22}$ Thus, the event that is the placement of gas vapors in a ship's hold and the state of its presence at the time of the ship's explosion do not intervene between the defendant's negligent act (dropping a plank) and the explosion caused by the sparks generated by the plank. ${ }^{23}$ Contrast that scenario with one in which the gas vapor had been introduced after the

21. See, e.g., Beale, Recovery, supra note 7, at 87; Smith, supra note 9, at 321-27; and each of the works by Hart and Honoré, supra note 13.

22. See the case citations and discussions in HaRT \& HonORE, CaUSaTion (2d ed.), supra note 13, at 79-80, 172-76; Beale, Proximate Consequence, supra note 7, at 641; Bohlen, supra note 8, at 162; Carpenter, Workable Rules, supra note 12, at 473-74, 476-84; and McLaughlin, supra note 11, at 159-64.

23. See In re Polemis, 3 K.B. 560 (C.A. 1921). 
defendant had negligently lit his pipe (which was still burning when the vapors were introduced); in this variation, the introduction of the gas vapors would have intervened between defendant's negligent act and the explosion.

This well-entrenched, temporal distinction often takes the form of the maxim, "You take your victim as you find him." ${ }^{24}$ No matter how abnormally or unforeseeably a person may be thin-skulled, a bleeder, an epileptic, a religiously scrupled person, ${ }^{25}$ or otherwise predisposed to injury, a defendant will be held to have caused the extensive injuries resulting from his normally harmless actions. The onset of the peculiar vulnerabilities of the victim, and the existence of those vulnerabilities at the time of the defendant's action, do not intervene between defendant's action and the harm.

This temporal limitation of interveming causes brings with it an ontological limitation as well. There is an old debate about what sorts of things can stand in the causal relation, that is, what sorts of things can be "causal relata."26 One subdebate here is between those who urge that only events can be causal relata and those who urge that states can also be causal relata. ${ }^{27}$ However one comes out in this more general debate, for intervening causes one must restrict causal relata to events. As Hart and Honoré put it: "If a contingency is . . . to negative causal connection it must be an event $[;]$. . . a state of the person or thing affected existing at the time of the wrongful act ... does not negative causal connection." ${ }^{28}$ This is not only a temporal distinction, but an ontological one as well: "The distinction [is] between an existing state of affairs and an intervening event."29

One can see why the ontological requirement is a corollary of the temporal requirement by returning to the facts of In re Polemis. There was in fact an interval of time between defendant's act, dropping the plank, and the harm, the explosion of the ship. ${ }^{30}$ During that interval, the state of gasvapor-being-in-the-hold did exist. One thus disqualifies such a state from being an intervening cause on the ontological ground that it is a state, not

24. Hart \& HonorE, Causation (2d ed.), supra note 13 , at 173,343 .

25. See Regina v. Blaue, 3 All E.R. 446 (C.A. 1975) (holding liable a defendant who stabbed a victim who subsequently died at the hospital because she refused blood transfusion in accordance with her Jehovah's Witness faith).

26. To my knowledge, Jaegwon $\mathrm{Kim}$ has done the most to reintroduce this issue into modern discussions of causation. See Jaegwon Kim, Causes and Events: Mackie on Causation, 68 J. PHIL. 426 (1971).

27. The states/events debate is discussed briefly in Michael Moore, Placing Blame: A General Theory of the Criminal Law 344-45 (1997).

28. HART \& HonORE, Causation (2d ed.), supra note 13, at 172.

29. Id.

30. Temporally locating acts and other events is itself a tricky metaphysical issue. I elsewhere defend at length the view that the defendant's act in a case like In re Polemis ends with that movement of his body that caused the plank to drop. See MrchaEl S. Moore, Act AND Crime: The Philosophy of ACTION AND ITS IMPLICATIONS FOR CRIMINAL LAW (1993). 
an event, whereas, in my contrasting hypothetical, the introduction of the gas vapor is an event and thus is eligible to serve as an intervening cause. This is to use an ontological distinction as well as the temporal distinction to make out intervening causation.

It is natural that those who favor a foreseeability approach to proximate causation will find the temporal/ontological distinction problematic. ${ }^{31}$ After all, whether an extraordinarily unlikely thing occurs before or after a defendant's act, and whether that thing is an event or a state, makes no difference to the foreseeability of the harm that such a state or event makes possible; defendant can reasonably be ignorant of such a thing no matter what it is or when it comes into existence. The proper conclusion to draw from this, however, is that foreseeability has nothing to do with intervening causation. If we are restricting ourselves to a causal inquiry, not a culpability inquiry, we properly focus on what intervenes between defendant's act and the harm. All that went before has nothing to do with defendant's causal responsibility in bringing about some harm. Whether a world is extraordinary or dull, monotonous or uniform, is all one for the causal inquiry. Whichever it is, it is the stage on which defendant begins his causal contribution. ${ }^{32}$

\section{The Independence Condition: Intervening Causes Must Not Themselves Be Caused by Defendant's Action}

Another strand of the idea of "intervention" is the newness of that which intervenes. This strand is well captured by the English label "extraneous cause." To intervene between defendant's act and his victim's harm, an event must not itself be the product of defendant's act. If it is such a product, then the event is merely part of the mechanism or means by which defendant's act caused the harm; it is not an intervention preventing such causation by defendant.

Hart and Honoré give this example: A defendant who culpably pushes his victim to the ground is not liable for that victim's death when the victim is killed on the ground by a falling tree. ${ }^{33}$ The falling tree, in such a case, intervenes between defendant's push and the victim's death. By contrast, if the defendant's push caused the victim to stagger into a rotten tree, and the impact caused it to fall and kill the victim, the defendant is held to have caused the death. While the tree's falling was subsequent to the defendant's act of pushing, it was not causally independent of the push and so does not constitute an intervening cause.

31. As does Glanville Williams, for example. See Glanville Williams, Causation in the Law, 1961 CAMBridge L.J. 62, 81-83.

32. See Hart \& Honoré, Causation (2d ed.), supra note 13, at 172, 179-80.

33. See id. at 77-79. 
There is considerable case law support for the independence criterion of intervening cause. ${ }^{34}$ Consider the example of Bunting v. Hogsett. ${ }^{35}$ Defendant's culpable act consisted of operating a railroad engine at too great a speed. To avoid a collision with plaintiff, defendant reversed throttle, shut off the steam, and jumped. The collision occurred anyway, but did not injure plaintiff. The collision, however, opened the engine's throttle, and the engineer-less train backed with increasing velocity around its track (which met plaintiff's road a second time), again hitting the plaintiff and this time injuring him. None of these rather extraordinary events were causally independent of defendant's culpable act, and so none of such events were held to constitute an intervening cause. As the Pennsylvania Supreme Court described its rationale:

$[\mathrm{N}] \mathrm{o}$ intermediate cause, disconnected from the primary fault and self-operating, exist[ed] in this case, to affect the question of the defendant's liability; it was the engineer's negligence that caused the first collision, and what occurred in consequence of this collision was not broken by the intervention of any independent agent, whatever. The first collision ... opened the throttle, and turned loose the destructive agency which inflicted the injuries complained of. ${ }^{36}$

Presumably, had the engine's throttle been set in reverse and opened up by a child at play, a bolt of lightning, or virtually anything else with a genesis independent of the first collision, the court would have deemed such events interveming causes.

The older literature on interveming cause regarded causal independence as an unproblematically universal requirement for intervening causes. ${ }^{37}$ Yet as McLaughlin, ${ }^{38}$ Carpenter ${ }^{39}$ and Hart and Honore ${ }^{40}$ came to see, with regard to certain kinds of interveming causes, some qualifications have to be made.

Consider first intervening voluntary actions by human agents exploiting the situation created by defendant's culpable action. As Hart and Honoré recognize,

34. See id. at 176-78, 347; see also the case law summaries in Beale, Proximate Consequence, supra note 7, at 646; Bohlen, supra note 8, at 157-58, 162-63; Carpenter, Workable Rules, supra note 12, at 484-85; Terry, supra note 10, at 20.

35. 21 A. 31 (Pa. 1891). The case is relied on by the Restatement (SECOND) OF ToRTs, § 435 cmt. a (1965); by HART \& Honoré, CAUSATION ( $2 \mathrm{~d}$ ed.), supra note 13, at 176-77; and by Bohlen, supra note 8 , at $157-58$.

36. $21 \mathrm{~A}$. at 32 (emphasis added).

37. See the extended discussion in Levitt, supra note 12, at 55-60; see also Bohlen, supra note 8, at 162-63; Terry, supra note 10, at 20.

38. See McLaughlin, supra note 11, at 173-75.

39. See Carpenter, Workable Rules, supra note 12, at 526-39.

40. See Hart \& Honoré, Causation (2d ed.), supra note 13, at 136, 181-85. 
[A] voluntary act which negatives connection will always be found to be in some sense dependent on [defendant's original wrongdoing], e.g., it will be motivated by the fact that the wrongful act has occurred or by the belief that it may occur. It will be done in response to or in anticipation of some untoward situation. ${ }^{41}$

As an example of this last point, consider the facts of Watson $v$. Kentucky \& Indiana Bridge \& Railroad $\mathrm{Co}^{42}$ The defendant negligently spilled its gasoline throughout the town. The subsequent fire, however, was caused by the intervention of a third party; such person either dropped his cigar negligently into the petrol or intentionally threw it in to ignite a blaze. The court held that if it was the latter situation, the act of throwing the cigar would constitute an intervening cause and relieve the defendant of liability for the fire. In such a case, Hart and Honore would point out, the intervenor's act in some sense is not causally independent of the defendant's act, for the intervenor's act is made possible by the act of the defendant and in that sense is done in response to the defendant's act.

While all of this is quite in accordance with case law and commonsense notions of causation, unnoticed by Hart and Honore is the continued power of the independence criterion, even in the cases of intervening voluntary human action. Consider first intentional third-party intervenors, such as the second factual possibility in Watson above. As McLaughlin ${ }^{43}$ and before him Beale ${ }^{44}$ observed, it is generally true that "stimulated voluntary action" 45 by a third-party intervenor will not constitute an intervening cause. That is, if the defendant coercively supplies the motive for the intervenor's behavior, then that behavior does not break the causal chain between defendant's action and the harm. Whereas, as Bohlen put it long ago, if the intervening voluntary act "divert[s] the natural results of the wrong to some new and different end," cause. In Watson itself, the intervenor threw his cigar for his own, independent reasons. His motivation was in no way dependent on defendant, even if his action was made possible by defendant's negligence.

Hart and Honore do not so much disagree with this analysis as they reclassify it. Rather than talk of independence of motivation, they smuggle the same requirement into their concept of "voluntariness." Where the defendant threatens or pressures the intervenor into doing what he does, they, like McLaughlin and Beale before them, recognize that such "stimulated action" does not constitute an intervening cause. This is one of

41. Id. at 136 .

42. 126 S.W. 146 (Ky. 1910).

43. See McLaughlin, supra note 11, at 173 .

44. See Beale, Proximate Consequence, supra note 7, at 646-49.

45. The phrase is McLaughlin's. See McLaughlin, supra note 11, at 173.

46. Bohlen, supra note 8 , at 163. 
Hart and Honoré's categories of "nonvoluntary" action, as we shall see.47 The intervenor choosing on his own to exploit the situation created by the defendant's wrongdoing is their paradign case of voluntary action constituting an intervening cause..$^{48}$

Consider secondly intervening voluntary acts in which the intervenor does not intentionally bring about the harm. In Watson, this is the negligent thrower of the cigar, one who does not know the gasoline to be present (although he should). With considerable support in the case law, ${ }^{49}$ Hart and Honoré observe that negligent action by an intervenor merely reactive to defendant's wrongdoing does not constitute an intervening cause. ${ }^{50}$ Hart and Honoré cast this again as a nonvoluntary/voluntary distinction, but it is easy to see the causal independence criterion at work here as well.

Hart and Honoré also except animal behavior and involuntary human conduct from the independence requirement. That is, according to their theory, while an independent event of these kinds will always qualify as an intervening cause (if other requirements are met), sometimes a dependent event will also qualify if it is of one of these two kinds. For animals, if the interveming behavior of the animal is not in accordance with the nature of an animal of the kind in question, then that behavior, though causally dependent upon defendant's wrongdoing, may still constitute an intervening cause. ${ }^{51}$

Examples of such dependent animal behavior that nonetheless negatives causal connection are hard to come by. Most cases are like City of Waco $v$. Branch. ${ }^{52}$ Defendant city negligently released its sheep from their pens located on inunicipal park land. A dog chased the sheep onto the

47. See Hart \& Honoré, Causation (2d ed.), supra note 13, at 144-45.

48. See id. at 136-37. The intermediate cases are those in which the defendant supplies the motivation for the intervenor, but does so by way of offers, encouragements, requests, and the like, rather than by threats or pressure. Hart and Honore rightly observe that there is liability in such cases, and on "causal or quasi-causal grounds," so one could easily account for these cases on the independence criterion: Since the intervenor's motive was supplied by the defendant, there is no motivational independence and therefore no break in causation. I have urged, however, that in such cases there is no causal basis for liability; rather, in torts and in criminal law, defendants are held as an accomplice (or as a joint tortfeasor by virtue of actions in concert, rather than joint causation). See Moore, supra note 2, at 34-41. For me, the independence test here is thus trickier. Still, the difference between an offer and a threat lies precisely in what the recipient of the offer brings to his decision to accept: In the case of true offers (as opposed to "offers one cannot refuse"), the recipient who accepts finds reasons sufficient for his choice within himself, whereas in yielding to a threat the recipient has his motivation supplied by the coercive consequences threatened.

49. See Carpenter, Workable Rules, supra note 12, at 526-39 (dealing with acts done to avert threatened harm to the intervenor, to rescue others from threatened harm, to mitigate or repair damage done by defendant's act, to prevent deprivation of rights, and to defend from attack).

50. See HART \& HonorE, Causation (2d ed.), supra note 13, at 152; see also Burke, supra note 12 , at 11 ("Courts often will not relieve a defendant where the intervening act, even though negligent, was motivated by a desire to prevent defendant's act ... from causing some apparent damage.").

51. See Hart \& HonorÉ, Causation (2d ed.), supra note 13, at 182, 348.

52. 8 S.W.2d 271 (Tex. Civ. App. 1928). 
roadway in front of plaintiff's car. Plaintiff wrecked his car and injured himself in avoiding the sheep. Carpenter concluded that the city should properly be held liable, despite the causal dependence of the dog's intervention upon the defendant's wrong. As Carpenter put it, "The defendant's wrong in leaving the sheep in the park was a cause-in-fact of the dog's chasing them." 53

Causal independence is a better theory to apply to such cases than is Carpenter's "foreseeability" or Hart and Honoré's "in the nature of the beast" criteria. One has to get away from "but for" causation in assessing the causal independence of the intervention from the defendant's wrong. I would say, in the City of Waco situation, that the dog's intervention was causally independent of the defendant's act. Defendant's wrong in unpenning the sheep provided the opportunity for the dog's intervention, and in that anemic sense it made possible (was a necessary condition of) the dog's act. But the defendant's wrongful act gave no impetus to the dog to chase the sheep-no more so than the provision of opportunity to voluntary human intervenors, who when they exploit the situation presented by defendant's wrong do so for their own reasons. Contrast such a case with the facts in Isham v. Estate of Dow ${ }^{54}$ where defendant's wrong of shooting a dog sent the dog scurrying for cover in plaintiff's house, knocking plaintiff down and injuring him. There, the dog's behavior is truly causally dependent on defendant's wrong and was properly held not to be an intervening cause.

According to Hart and Honoré, the cases also except certain intervening involuntary human acts from the causal independence requirement. On their reading of the cases, even a causally dependent involuntary act may "negative causal connection if not in accordance with human nature." 55 There is very little authority cited for this proposition, however. In Commonwealth v. Root ${ }^{56}$ for example, one of the cases cited by Hart and Honore, ${ }^{57}$ the court held that defendant's act of starting an auto speed contest was not the proximate cause of a subsequent crash because the victim (who was the other racer) recklessly swerved into oncoming traffic during the race; there is no mention of human nature in the court's opinion, nor is it obvious that such recklessness isn't pretty natural for road racing. Hart and Honore's more general formula for dealing with intervening recklessness and negligence seems more apt, ${ }^{58}$ if the reckless or negligent intervening action was done to escape or thwart the danger created by defendant's wrong, then it is not an intervening cause, whereas if the

53. Carpenter, Proximate Cause (pt. 3), supra note 12, at 16.

54. 41 A. 585 (Vt. 1898).

55. HART \& HONORÉ, CAUSATION (2d ed.), supra note 13, at 183, 350.

56. 170 A.2d 310 (Pa. 1961).

57. See Hart \& Honore, CAUsation (2d ed.), supra note 13, at 350.

58. See id. at $152,335-36$. 
intervening act is independently motivated (as it was in Root), then it can constitute an imtervening cause.

Construing causal independence in this motivational manner for intervening hunian and animal actions allows us to retain the uniform requirement that a subsequent event must be independent of the defendant's wrong if it is to negative a causal connection between that wrong and some harm. The earlier writers on intervening causes were thus closer to the truth than they knew.

\section{The Core of the Doctrine of Intervening Causation: Three Kinds of Chain-Breakers}

\section{a. Voluntary Human Actions}

The guts of the intervening-cause doctrine lie in what (subsequent, causally independent) events qualify as intervening causes. Most theorists have focused their attention on voluntary interventions by third-party wrongdoers. Some of our clearest intuitions of causal chains being broken lie here; judges, too, have shared these intuitions in buildmg a considerable body of case law.

The Watson case discussed earlier provides an exainple..$^{59}$ If Duerr, the cigar sinoker, intentionally threw his cigar onto the gasoline that defendant railroad, by its negligence, had spilled into the city streets, and he did so m order to ignite the gasoline, then his action would constitute an intervening cause. Even though it was defendant's negligently spilled gasoline that soaked the town, Duerr's voluntary intervention was a fresh causal start making him alone causally responsible for the fire damage.

"Voluntary" is given quite an extended meaning in intervening causation doctrine. It includes principally: (1) voluntariness of action in the law's more usual sense, (2) accompanied by an intention to bring about the harm or, sometimes, foresight or even negligence, (3) which intention is formed in the absence of coercive pressure making the choice difficult, (4) by one sufficiently possessed of his faculties as to be a generally responsible agent. Let us consider these briefly one at a time. ${ }^{60}$

\section{i. Voluntariness of Action in the Law's Usual Sense}

To be an action at all, behavior must be voluntary in the sense used in criminal law and torts when assessing the defendant's (not the intervenor's) conduct. ${ }^{61}$ In Watson, ${ }^{62}$ if Duerr had dropped his cigar by reflex

59. See supra text accompanying note 42.

60. For an overview (although not in my four categories in the text), see HART \& HONORÉ, Causation (2d ed.), supra note 13, at 41-44, 74-77, 136-62, 326-40.

61. For a discussion of the meaning of "voluntary" in the criminal law's voluntary act requirement, see MOORE, supra note 30 , at 6-8, 17-59, 245-79.

62. See supra text accompanying note 42 . 
reaction, done so while asleep, unconscious, or under hypnosis, had the cigar knocked from his hand by another, a gust of wind, or a passing trolley, he would not have acted; in such cases, his cigar would have dropped from his hand as the leaves drop from trees, which is to say he did nothing causing it to drop. At a minimum, for Duerr's behavior to be an intervennig cause, such behavior cannot consist of involuntary bodily novement.

When assessing the defendant's conduct, usually it is said that omissions to prevent sonie harm do not constitute a voluntary act unless the defendant was in one of the exceptional situations where he had a positive legal duty to prevent such harm. For the intervening actor, fortunately, the situation is not clouded with distinctions based on legal duties. Rather, omissions are not voluntary acts even where the intervening actor was under a legal duty not to omit. ${ }^{63}$ Omissions, on the best conceptualization of them, are literally not things at all; they are the absence of certain events. ${ }^{64}$ It is difficult to see how they could intervene as a new cause when they cannot constitute any kind of cause at all..$^{65}$

\section{ii. The Intervenor's State of Mind}

The second aspect of "voluntariness" for these purposes has to do with the intervenor's state of mind. In the clearest cases of intervening causation, the intervening actor intends to exploit the opportunity left by defendant's wrongdoing, and he intends by his intervening act to accomplish the very harm for which the defendant is charged. In Watson ${ }^{66}$ if Duerr threw his cigar intending to torch the village, his act would constitute an intervening cause relieving the defendant railroad of liability because of its negligently spilled gasoline. Such an intent (when motivating an action that is subsequent and causally independent) is thus almost always sufficient to break the causal chain and relieve defendant of liability ${ }^{67}$ But is such intent necessary for a human act to be an intervening cause?

63. See RESTATEMENT OF TORTS $\$ 452$ (1934) ("Failure of a third person to perform a duty owing to another to protect him from harm thrcatened by the actor's negligent conduct is not a superseding cause of the other's harm."); see also Carpenter, Workable Rules, supra note 12, at 485-90 ("IIn nearly every case when the question has arisen an omission has been held not to constitute an intervening cause."). Hart and Honore are extremely unsympathetic to this doctrine, but this seems mostly due to their extreme lack of sympathy with there being any distinction bctween acts and omissions worth marking. See HART \& HonORE, CAusation (2d ed.), supra note 13, at 138-41.

64. See MOORE, supra note 30, at 22-34; MOORE, supra note 27, at 262-72.

65. On the inability of omissions to be any kind of cause, intervening or otherwise, see Mooke, supra note 30, at 267-76; Moore, supra note 27, at 273-74; Paul K. Ryu, Causation in Criminal Law, 106 U. PA. L. REv. 773, 779 (1958) ("One of the basic axioms in natural science is that 'nothing' cannot produce 'something."'). Julie Andrews probably said it best in Rodgers and Hammerstein's The Sound of Music: "Nothing comes from nothing, and nothing ever could."

66. See supra text accompanying note 42.

67. Two large qualifications are in order here. One has to do with foreseeability. Many cases have said that even a fully intentional causing of the harm by a third-party intervenor will not rclieve a 
In their article ${ }^{68}$ and in the first edition of their book, ${ }^{69}$ Hart and Honore thought so. By the second edition, however, they realized that they had to account for those numerous cases where the intervening actor is held to be an intervening cause despite the lack of any intention to cause the victim harm. Their revised description of the doctrine is that a "deliberate, informed" act "intended to exploit the situation created by defendant" is sufficient to constitute an intervening cause. ${ }^{70}$ Their example is of an intervenor who decides to rob a victim rendered unconscious by defendant's negligence; if the intervenor accidentally injures the victim, defendant will not be responsible for such injury. "This is because the decision to exploit the situation by stealing from the pedestrian has intervened ... even though, in executing it, the thief has brought about a consequence which he did not intend."71

In examples like these, it is inevitable to attribute some degree of culpability to the intervenor: if not intention, then foresight, recklessness, or negligence with respect to the harm suffered by the victim. This is the grain of truth in the older maxim that criminal conduct by an intervenor is sufficient to constitute an intervening cause. ${ }^{72}$ Yet this maxim suffered from serious overbreadth. Not any reckless or negligent act will suffice to create an intervening act. As Hart and Honoré recognize, "every merely negligent act is nonvoluntary in our sense, since by hypothesis the actor did not intend to exploit the situation" created by defendant's wrong. ${ }^{73}$ The actor must have enough knowledge of the circumstances created by defendant's wrong that his decision to go ahead is properly viewed as a decision

defendant of liability if the intervention was foreseeable to the defendant at the time that he acted. As I discuss below, foreseeability has no place in the doctrines of intervening causation. Plus, the concept is so fully manipulable, see MoORE, supra note 27, at 363-99, that what courts do in fact (as opposed to what they may say they are doing) is to treat intervening intentional wrongdoing as per se unforeseeable, even when we know that it is not.

A second complicating factor hes in the kind of cases Hart and Honore categorize as "provision of opportunity" cases. See HART \& HoNORÉ, CAUSATION (2d ed.) supra note 13, at 59-61, 81-82, 194204, 374-77. In those cases the intervention by a third-party wrongdoer is not merely foreseeable to the defendant; rather, it is precisely the likelihood of some such intervention that makes defendant negligent to start with. Leaving ignition keys in automobiles, for example, is negligent precisely because wrongdoers may steal them. Hart and Honore seek to except out such cases from the general rule stated in the text. By contrast, I have argued that the rule stated in the text makes no exception for such cases; there often is liability in such cases, but it is a noncausal liability (for failing to prevent such intervening wrongdoing). See Moore, supra note 2, at 36-38.

68. See Hart \& Honoré, supra note 13, at 267.

69. See HaRT \& Honork, CaUSATION (1st ed.), supra note 13.

70. HaRT \& HonorÉ, Causation (2d ed.), supra note 13, at 136. In a review of the first edition of their book, Luke Cooperrider had gently protested that the cases rather often allowed merely negligent intervening actions by third parties to break causal chains. See Luke Cooperrider, Causation in the Law, 58 Mich. L. REv. 951, 954-55 (1960) (book review). See generally Eldredge, supra note 5, for many such negligence cases.

71. HaRt \& HonorÉ, Causation (2d ed.), supra note 13, at 151.

72. See Beale, Proximate Consequence, supra note 7, at 657.

73. Hart \& Honoré, Causation (2d ed.), supra note 13, at 138. 
to take advantage of those circumstances. Such a decision may be merely reckless or negligent and still constitute an intervening cause, ${ }^{74}$ but negligence or even recklessness by the intervening actor in failing to learn of such circumstances is not enough.

The only caveat to this is when the behavior of the intervening actor is so extraordinary that, although only negligent, it nonetheless fits the criterion (described below) of "abnormal natural events." If defendant's negligence has left the victim unconscious and with a broken arm, yet a doctor treats the patient with kerosene-soaked rags for fever, not noticing the broken arm, and the patient is severely sickened, the defendant should not be liable for the more severe sickening; the doctor's negligence would doubtlessly be categorized as gross negligence for the purpose of a suit against her but (more to the point in this context) such extraordinarily negligent behavior may well constitute an intervening cause by reason of its abnormality. ${ }^{75}$

\section{iii. Absence of Coercion}

The third feature inaking an intervening choice fully voluntary in the relevant sense is suggested by the adjective "free." define "free" in the compatibilist manner familiar from Herbert Hart's earlier writings:" A human agent is "most free when he is placed in circumstances which give him a fair opportunity to exercise normal mental and physical powers and he does exercise them without pressure from others." I I call this a compatibilist sense of "free" because it does not rely on any contra-causal kind of freedom; an act may be fully caused and yet "free" (in this compatibilist sense) in that the actor was possessed of adequate capacity to decide what to do and was given a fair opportunity to exercise that capacity. ${ }^{79}$

The factors that can erode adequate capacity or fair opportunity for free, unpressured choice are numerous. A threat of serious bodily harm, or of damage to property, or a threat of economic injury, can so reduce the intervenor's options as to render his choice to intervene nonvoluntary. "Threats" by natural circumstance can similarly reduce opportunities; if one's choice is reduced to burning to death or jumping to one's likely injury, the jump is involuntary and does not constitute an intervening

74. See id. at 141-42, 152-53.

75. See id. at 184 .

76. Id. at 136.

77. See H.L.A. Hart, Legal Responsibility and Excuses, in DeTERMINISM AND FreEdom IN THE Age of Modern ScIENCe 81 (Sidney Hook ed., 1958), reprinted in H.L.A. HART, Punishment and RESPONSIBILITY 28 (1968).

78. HART \& HONORE, CAUSATION (2d ed.), supra note 13, at 138.

79. I elaborate on Hart's adequate capacity/fair opportunity sense of frccdom in Moore, supra note 27 , at $481-592$. 
cause. Likewise, strong emotions, such as fear, provoked anger, addictive cravings, and the like may so incapacitate an intervenor as to render his choice nonvoluntary. ${ }^{80}$ It is important to see that such threats, natural necessities, or emotional reactions need not originate with the defendant in order to make an intervening choice nonvoluntary. As we saw earlier, ${ }^{81}$ if such items did originate with the defendant, then the intervenor's choice lacks causal independence and cannot be an intervening cause on that ground alone. It is where such iteins originate other than with the defendant that such nonvoluntariness disqualifies a choice on its own hook. It is defects in the intervenor's choice itself, not a causal connection of that choice to the defendant's action, that is doing the work here. Nonvoluntary choices are incapable of breaking the causal chains that may be broken by fully voluntary human decisions.

\section{iv. Capacity Necessary for Voluntariness}

Fourth, if the intervenor's general capacity to make choices is eroded, such intervening choices as he does make do not constitute intervening causes. The insane, those diminished in mental capacity due to mental disease, drugs, or alcohol, and the very young all lack the kinds of capacity that would enable their choices to qualify as interveming causes. ${ }^{82}$ These are not compelled choices (see number three above) or ignorant choices (see number two above) so much as they are defectively reasoned choices. Only the chosen actions of sane, sober, adults can constitute intervening causes (unless insane or immature choices are so abnormal as to qualify as intervening causes on that distinct ground).

If one considers these four conditions of nonvoluntariness together, we can see the descriptive power of the old last-wrongdoer rule. For the voluntary act, mens rea, absence of coercion, and general capacity requirements pretty much constitute the conditions we use to assess culpable wrongdoing generally. As Hart and Honoré recognize, "the various circumstances [of voluntariness for intervening cause purposes] correspond with the factors which diminish moral and legal responsibility." ${ }^{183}$ Even so, not all culpable wrongdoing constitutes an intervening cause when it intervenes temporally between defendant's act and some harm, and not even all causally independent wrongdoing so qualifies. Holmes's old view is the right one here: While "the general tendency has been to look no further back than the last wrongdoer,"

80. All such cases are discussed in HART \& HONORÉ, CAUSATION (2d ed.), supra note 13, at 144149, 155-57, 330-35. See also Carpenter, Proximate Cause (pt. 3), supra note 12, at 72-86.

81. See supra text accompanying notes 36-54.

82. See HART \& HoNORE, CAUSATION (2d ed.), supra note 13, at 153-56.

83. Id. at 138 .

84. Clifford v. Atlantic Cotton Mills, 15 N.E. 84, 87 (Mass. 1888). 
qualifications that it cannot be elevated into the hard and fast rule the lastwrongdoer rule purported to be.

\section{b. Abnormal Natural Events}

Even if a subsequently arising, causally independent event does not qualify as a fully voluntary human act, that event may yet qualify as an intervening cause if it is in some sense "extraordinary." Such extraordinary events inay be natural events, like floods, storms, and earthquakes, or they may be human actions. In either case, "acts of God" or "coincidences" may break causal chains as surely as the most deliberate intervention by a thirdparty wrongdoer.

Hart and Honoré helpfully subdivide these cases into two kinds: events that are abnormal in almost any context, and events that are abnormal in conjunction with certain other events. ${ }^{85}$ Meteorites, unprecedented winds or rains, ${ }^{86}$ tidal waves, extraordinary floods, and the like are exainples of the first kind, usually called vis major or "acts of God." Trees falling just where some victim has been placed by defendant's wrongdoing ${ }^{87}$ and lightning igniting explosive dust negligently spilled by defendant into his warehouse ${ }^{88}$ are examples of the second kind, aptly terined "coincidences." It is not unusual for trees to fall or lightning to strike; what is extraordinary is that such events should have happened just where and when they did, which was the only time and place at which they could have caused injury to a victim made susceptible to such injury by defendant's wrongful act. ${ }^{89}$

Hart and Honoré nicely distinguish three rather glaring indeterminacies in the use of this abnormality criterion. ${ }^{90}$ Most obvious is the indeterminacy stemming from the degree-vagueness of "abnormal": Just how extraordinary niust an event (or conjunction of events) be in order to qualify as abnormal? ${ }^{91}$ Light winds ordinary in the evenings for a given place are obviously not abnormal, while winds of unprecedented force are

85. See Hart \& HonorE, CaUSATION (2d ed.), supra note 13, at 163.

86. See Kimble v. Mackintosh Hemphill Co., 59 A.2d 68 (Pa. 1948).

87. This is Hart and Honore's example. See Hart \& Honore, Causation (2d ed.), supra note 13, at 78; cf. Berry v. Borough of Sugar Notch, 43 A. 240 (Pa. 1899) (holding irrelevant the plaintiff's much earlier negligent speeding, even though that speeding placed him just where a tree happened to fall on him).

88. This is the hypothetical framed by the court in People v. Wamer-Lambert Co., 414 N.E.2d 660 (N.Y. 1980).

89. I ignore a distinction Hart and Honore draw within the coincidence cases; they separate out coincidences of time and place on the ground that in such cases, it does not matter how unlikely the conjunction might be, such coincidence still intervenes. See Hart \& Honort, CaUsation (1st ed.), supra note 13, at 157; CAUSATION (2d ed.), supra note 13, at xxxix, 168-70. I ignore the distinction because the time/place cases are some of the best examples of coincidences precisely because of the unlikelihood of such conjunctions.

90. See HaRT \& HonORE, CaUSATION (2d ed.), supra note 13, at 165-68.

91. See id. at 168. 
abnormal; in between these extremes, one can only say, "highly unlikely," "extremely unlikely,"93 or "very unlikely." "94

The second indeterminacy is a bit less obvious. It stems from the fact that when assessing probabilities, we never assess the probability of a particular event. ${ }^{95}$ Rather, we assess the probability of soine event occurring that instantiates the type of event in which we are interested. Although idiomatic English misleads us here, when we ask, "What was the probability of that storm?" we actually mean, "What was the probability of some storm occurring where and when this one did?" Hence, indeterminacy number two: it is indeterminate what types we mean to use when we assign degrees of likelihood. Do we mean, for example, some instance of the type, rainstorm? Long rainstorm? Long, one-inch-per-hour rainstorm? Since probabilities differ considerably by the type one has in mind, the indeterminacy in assessing degrees of abnormality is a significant issue. ${ }^{96}$

Hart and Honore attribute to the law what they call the plain man's view: "It will in general be enough to take the description of the events which would ordinarily be given."97 As they recognize, this does not uniquely determine types, but perhaps it restricts the range of variation somewhat.

The third indeterminacy is the uncertainty about the epistemic vantage point from which the assessinent of likelihood is to be made. As Hart and Honore recognize, "like the cognate idea of what is 'foreseeable," 'probable,' or 'within the risk,' the idea of coincidence is essentially a function of limited knowledge of the events concerned." That is, from an omniscient epistemic vantage point, the likelihood of soine instance of some type of event occurring during a given interval of time is either 0 or 1 (assuming a deterministic universe). For all of us less-than-omniscient mortals, the probability depends on what we know..$^{99}$

One could assess the likelihood of a given conjunction of events from the epistemic vantage point of the defendant: Given what the defendant knew or should have known, what likelihood would he have assigned if he were reasonable? This collapses abnormality into foreseeability. Preferable for these purposes is to repair again to the ordinary person's view. From the epistemic vantage point of most of us, the observers, what would we (in retrospect) judge the probability to have been? Although abnormality is

\footnotetext{
92. William L. Prosser, HaNdBook of the LaW of ToRts 276 (4th ed. 1971).

93. HART \& HoNORE, CAUSATION (2d ed.), supra note 13, at 400.

94. Id. at 168 .

95. See MOORE, supra note 27 , at 382-89.

96. See id. at 389-95.

97. HART \& HonORE, CaUSATION (2d ed.), supra note 13, at 166.

98. Id. at 165.

99. On the essentially epistemic nature of probability judgments, see Heidi M. Hurd, The Deontology of Negligence, 76 B.U. L. REV. 249 (1996).
} 
like foreseeability in that both are probabilistic notions, the epistemic vantage point froin which probability is to be assessed differs.

\section{c. Intervening Preemptive Causes}

In the older literature on intervening causation it is often suggested that an event will be an intervening cause if it is "sufficient" by itself to have caused the harm. As the U.S. Supreme Court once opined:

One of the inost valuable of the criteria furnished us by these authorities is to ascertain whether any new cause has intervened between the fact accomplished and the alleged cause. If a new force or power has intervened of itself sufficient to stand as the cause of the misfortune, the other must be considered as too reinote. ${ }^{100}$

Terry and others were unable to find any clear meaning to "sufficient" in such cases. ${ }^{101}$ My own interpretation of this criterion would be as follows.

It is well known that overdetermination cases pose thorny problems for many theories of causation. ${ }^{102} \mathrm{~A}$ case is one of "overdetermination" when two independent events are each sufficient to produce a single, indivisible harm. For example, two individuals, not in concert, each negligently start a fire; each fire is sufficient to destroy the victim's house; as it happens, the fires join and the resultant fire destroys the house. Each is held to be a cause of the destruction..$^{103}$

- More relevant for our purposes are a subclass of the overdetermination cases, those often dubbed "preemptive" (as opposed to concurrent) overdetermination cases. ${ }^{104}$ For example, the two negligently set fires do not join; defendant's fire reaches the victim's house first and destroys it; the other fire then arrives sufficient to have destroyed the house if it were still standing, but there is no house left to destroy. Defendant's fire is said to have preempted the other fire as the cause of the destruction.

Often a preeinptive cause does its work after the factor preempted has begun to do its work. Examples: defendant poisons the victim, but as the viction is dying of the poison another comes along and shoots the victim

100. Insurance Co. v. Tweed, 74 U.S. (7 Wall.) 44, 52 (1868); see also Milwaukee \& St. Paul Ry. v. Kellogg, 94 U.S. 469, 475 (1876) ("We do not say that even the natural and probable consequences of a wrongful act or omission are in all cases chargeable to the misfeasance or nonfeasance. They are not when there is a sufficient and independent cause operating between the wrong and the injury. In such a case the resort of the sufferer must be to the originator of the original cause.").

101. See Terry, supra note 10 , at 21 ; Smith, supra note 9, at 326-27.

102. The best contemporary legal discussion of these cases is Richard W. Wright, Causation in Tort Law, 73 CALIF. L. REv. 1737, 1775-98 (1985); see also Moore, stura note 2, at 9-13, 29-30, 46, 49-50.

103. See Andersou v. Minneapolis, St. Paul \& Sault Ste. Marie Ry., 179 N.W. 45 (Minn. 1920); Kingston v. Chicago \& N.W. Ry., 211 N.W. 913 (Wis. 1927).

104. See Honoré, supra note 13, at 374-80; Moore, supra note 2, at 10; Wright, supra note 102, at 1775. 
dead; ${ }^{105}$ defendant's negligently constructed bridge allows victim to fall to what would be a certain death, but, as he is falling, victim is electrocuted by uminsulated wires; ${ }^{106}$ defendant pushes victim from a tall building but half-way down victim is shot and killed instantly by another, ${ }^{107}$ defendant seeks to kill victim by poisoning water needed by victim to cross a desert, but before victim drinks any poison another drains the poison from the keg and the victim dies of thirst; ${ }^{108}$ defendant inortally burns victim but before victim dies of the burns another kills victim instantly by a blow to the head; ${ }^{109}$ defendant's fire has begun to burn victim's property but before it can destroy much a flood extinguishes the fire and destroys victim's property. ${ }^{110}$

In all such cases the second factor that intervenes after defendant's action has taken place preempts the ability of defendant's action to cause the harm it was normally sufficient to cause. I call such subsequently arising, causally independent preemptive cause cases a third kind of intervening cause. For notice that the electrocution, the shots, the draining of the poisoned water, the blow to the head, and the flood in such cases may or may not qualify as intervening voluntary action or intervening abnormal natural events. Yet irrespective of their meeting either of these other two criteria, it is clear that such intervening events break the causal chain that would have existed between defendant's action and the harm. Thus, although it is uncommon so to classify them, I include such preemptive cause cases as a third kind of intervening cause, distinct from and in addition to voluntary human acts and abnormal natural events. It is such a preeinptive variety of intervening causes that is the best interpretation of "sufficient" in the older doctrine of intervening causation.

\section{An Absence-of-Culpability Condition: Defendant May Not Intend, Foresee, or Have Foreseeable to Him an Intervening Cause?}

There is a considerable body of case law and commentary that purports to attach a fourth general condition to intervening causation. I call it

105. See Wright, supra note 102, at 1798.

106. See Dillon v. Twin State Gas \& Elec. Co., 163 A. 111 (N.H. 1932).

107. See Jerome Hall, General Principles for Criminal Law 262 (1st ed. 1947).

108. This is a variation of McLaughlin's famous hypothetical. See McLaughlin, supra note 11, at $155 \mathrm{n} .25$. The standard view of who killed the victim in the desert is that the intervenor did so, given that the victim died of thirst rather than poison. See J.L. MACKIE, THE CEMENT OF THE UNIVERSE: A Study of Causation 45-46 (1974); Moore, supra note 2, at 12, 42; Wright, supra note 102, at 1802. Hart and Honore's long-held view was that neither defendant nor intervenor caused the victim's death because each was preemptive of the other (but each should be liable on some unspecified, noncausal basis). See HART \& HonORE, Causation (2d ed.), supra note 13, at 239-40. Tony Honore has recently recanted and joined the standard view here. See Honoré, supra note 13, at 378.

109. See State v. Scates, 50 N.C. 409 (N.C. 1858).

110. Hart and Honore give this example. See HART \& Honore, CaUsation (2d ed.), supra note 13 , at 239. 
an absence-of-culpability condition because it demands that a defendant not intend, foresee, or have foreseeable to him-that is, that he not be culpable with respect to - the putative intervening cause. I shall urge that this case law and commentary is entirely mistaken in presuming that the culpability of the defendant can affect the causal status of his action. If the legal doctrine of intervening causation has any claim to correspond to some underlying metaphysics of causation, it better not have any such culpability condition attached to it. ${ }^{111}$

\section{a. Where Defendant Either Intends the Harm, or Intends the Intervening Cause that Is that Harm's Means}

It is a sweeping maxim of the common law that no harm intended by the defendant can be too remote for liability to attach. As Terry stated the maxim, "Any intended consequence of an act is proximate." 12 This proposition is surely too broad. A defendant may intend to kill his victim by burns or by poison, yet if another intervenes, killing the victim by shots or blows to the head, the defendant has not caused the death of the victim, as we have seen. ${ }^{113}$ More generally, when the harm intended by the defendant only comes about through the imtervention of a causally independent cause of any of the three kinds just explored, the defendant is not liable for causing the harm ${ }^{114}$ (although he may be liable for attempt in criminal law).

Hart and Honoré sought to breathe new life into this old maxim by narrowing it. In their hands, the maxim became a fourth condition for intervening causation: If the defendant knows that a hurricane will hit victim's house, or knows that the victim's enemy will try to murder the victim at his house and defendant acts so as to cause victim to be in lis house at the time, then no matter how abnormal the hurricane or voluntary the murderer, defendant has still caused victim's death. ${ }^{115}$ We must exclude the possibility of "contrived coincidences" or of "contrived voluntary actions" if such items are eligible to be intervening causes, on their view.

Admittedly the cases better support this narrower use of intention, for there is liability of defendants in the cases cited by Hart and Honoré. Overlooked by Hart and Honore, however, is the possibility that there is only noncausal liability in such cases. ${ }^{116}$ In the case of voluntary intervention by human agents, defendants are liable but only as accomplices (in criminal law) or as noncausal joint tortfeasors (in torts). Defendants who persuade a victim to sleep in a house which defendants know will be

\footnotetext{
111. See generally Moore, supra note 2, at 28-31.

112. Terry, supra note 10 , at 17 .

113. See supra text accompanying notes 105-110.

114. See REstatement (SECOND) OF TORTS $\$ 435 A$ (1965).

115. See Hart \& HonORE, CAusation (2d ed.), supra note 13, at 170-71.

116. I explored this in some length in Moore, supra note 2, at 34-43.
} 
firebombed by another, ${ }^{117}$ or who wrongfully eject victim from their bar knowing that assailants are waiting outside, ${ }^{118}$ may be liable for the resulting injuries if they specifically intend such assaults to take place; yet this liability is for aiding another to cause such injuries, not for causing such injuries themselves. ${ }^{119}$

The same should be true for the contrived coincidence cases. The defendant who uses a foreseeable hurricane as his intended means to spread a fire he intentionally sets is liable for the whole damage; the proper grounds for such liability, however, is in aiding and not in causing. ${ }^{120}$ The hurricane remains an intervening cause breaking the causal chain between defendant's act and the harm, despite defendant's intention, but the possibility of a noncausal hability remams nonetheless.

I thus conclude that absence of intention by the defendant is not a proper criterion for determining the presence of an intervening cause. Whether defendants intend the harm, or $\mathrm{m}$ addition intend the intervening action or other event as the means to cause such harm, is irrelevant to intervening causation. Such intentional use of another is the precise target of noncausal accomplice liability, and such intentional use of the freaks of nature should be the target of an analogous noncausal liability for aiding nature.

\section{b. Where Defendant Foresees the Intervening Event Even if He Does Not Intend It}

Suppose one foresees the above-hypothesized hurricane or murderer intervening after one's acts, but is indifferent to the harm it will cause. In such cases one does not adopt the intervening events as intended means to the harm one intends. In criminal law at least, this absence of a specific intent to aid another by one's acts eliminates accomplice liability. ${ }^{121}$ So if there is hability in such cases, it cannot be on that noncausal basis.

Despite this, Francis Bohlen argued that a defendant's knowledge of such matters as predicted hurricanes or murderous intentions should exclude the events predicted or intended from the category of intervening causes. ${ }^{122}$ Thus, where defendant's negligence consisted in not removing his boats from blocking the victim's access to locks in a river that the defendant predicted would flood suddenly, the flood that did ensue and that

117. This is Hart and Honore's example. See Hart \& Honore, Causation (2d ed.), supra note 13 , at 171 .

118. See id.

119. For the causing/aiding distinction, see Kadish, Causation and Complicity, supra note 14;

Kadish, Theory of Complicity, supra note 14; Moore, supra note 2, at 34-36, 38-41.

120. See sources cited supra note 119.

121. See Model Penal Code $\S 2.06$ (1962).

122. See Bohlen, supra note 8, at 162. 
did sweep the victim's boat over a dam could not constitute an intervening cause because the result was foreseen by the defendant. ${ }^{123}$

I have elsewhere argued that liability may be proper in cases such as these, but it is again a noncausal liability. In such "provision of opportunity" cases, the defendant is liable for failing to prevent the injury that he clearly foresaw. ${ }^{124}$ The positive duty to prevent, in such cases, arises because the defendant has caused something (even if not the injury), namely, he has caused the victim's peril. One who culpably or innocently bumps another into the water has a duty of rescue, a duty not shared by those free of causal responsibility for the victini's peril. ${ }^{125}$ Similarly, one who places his boats so as to imperil plaintiff's boats has a duty to remove them. Failure in such positive duties, however, does not make one a cause of the harm. ${ }^{126}$ One is liable for failing to prevent it, but not for causing it. Liability in such cases is thus noncausal, and we do not need to tinker with the concept of intervening causation in order to accommodate liability in such cases.

\section{c. Where the Intervening Event Is Foreseeable to the Defendant}

The commentary on the foreseeability of intervening causes is extensive and uniform. Nearly all of the early commentators were agreed that the foreseeability of an intervening event was relevant to that event's status as an intervening cause. ${ }^{127}$ More specifically, the orthodox view was (and is) that unforeseeability of the intervention is a necessary condition for that intervention to be an intervening cause. ${ }^{128}$ On this view, we should add unforeseeability to the other three main criteria for intervening causes.

Hart and Honoré's contrary view came as a welcone dissent to this notion. ${ }^{129}$ Part of their disagreement stemmed froin a different reading of the cases: "When ... the intervening act is voluntary and is done with the deliberate intention of causing harm, it is at least doubtful, on the cases, whether the fact that the intervention was foreseeable is sufficient to render the wrongdoer liable for the ultimate harm." 130 Courts that have indulged the fiction that deliberate causing of harm is per se unforeseeable ${ }^{131}$ give support to Hart and Honoré's view, despite the lip service given in such cases to the unforeseeability requirement of intervening causation.

123. See Scott v. Hunter, 46 Pa. 192 (1863).

124. See Moore, supra note 2, at 34-38.

125. See Joshua Dressler, Understanding Criminal Law 83 (1987).

126. For omissions are never causes. See sources cited supra note 65.

127. As Charles Carpenter summarized his predecessors in this regard, "where causes intervene, the practically universal view is that if they are foreseeable proximate cause exists." Carpenter, Proximate Cause (pt. 3), supra note 12, at 312. See generally id. at 275-313.

128. See Restatement of TORTS $\S \S 447,448$ (1934); Prosser, supra note 92, at 266, 272, 276.

129. See sources cited supra note 13.

130. HART \& HoNORE, CAUSATION (2d ed.), supra note 13, at 280.

131. See Watson v. Kentucky \& Indiana Bridge \& R.R. Co., 126 S.W. 146 (Ky. 1910). 
Another facet of Hart and Honoré's dissent was the easy slippage that exists between foreseeability and abnormality. ${ }^{132}$ It is easy to slip from a judgment of improbability from an idealized epistemic vantage point ("abnormality") to a judgment of improbability from the epistemic vantage point of the defendant ("unforeseeability"). ${ }^{133}$ Hart and Honoré correctly observed that many decisions couched in terms of unforeseeability are in reality decisions based on intervening abnormal natural events.

Hart and Honorés major move to reconcile their view to the decided cases consists of their reallocation of the basis of liability in what they call the "provision of opportunity" cases. ${ }^{134}$ They recognize that there is and should be liability in those (common enough) cases where defendant's negligence consists precisely in her failure to anticipate some foreseeably intervening, harm-causing, voluntary human action or abnormal natural event. Where defendant is negligent in leaving the ignition keys in another's car precisely because he should reasonably anticipate loss of the car through theft, defendant is and should be liable to the owner for the loss of the car, despite the intervening voluntary act of the thief. Such liability, Hart and Honoré argue, is only "quasi-causal."135 Defendant has only "enabled" or "occasioned" the harm in such cases; he has not caused the harm, by the central meaning of that concept.

This is almost right, but the liability that does properly exist in the provision-of-opportunity cases is not even "quasi-causal" or "noncentrally causal"; it is not caused-based liability in any sense. As in the case of foreseen harm, here the liability is entirely omission-based. ${ }^{136}$ The defendant who fails to remove the keys is liable for failing to prevent the loss of the car, not for causing its loss. The duty to prevent the loss stems from earlier acts of the defendant, which placed the victim's car in peril, namely, parking where and when he did, and leaving the car with the keys in the ignition. These acts gave rise to the positive duty, failure in which is the true basis for liability here. Properly construed, liability in such cases thus places no demands on the concept of intervening causation. Liability not based on causation at all is irrelevant to intervening causation.

It is probably true that some cases using foreseeability of the intervention as a basis for liability cannot be explained away in one of these three ways. So let me add a fourth: Foreseeability is such a manipulable concept ${ }^{137}$ that any result that is intuitive on the basis of intervening-cause doctrines without the concept is also reachable with the concept.

132. See HaRT \& HonoRE, CaUSATION (2d ed.), supra note 13, at 278.

133. See supra text accompanying notes $98-100$.

134. See supra note 67.

135. HART \& Honoré, CAUSATION (2d ed.), supra note 13, at 194-204.

136. See Moore, supra note 2, at 36-308.

137. See supra note 67. 
To the extent that there are cases that are not explainable in one of these four ways, they should simply be regarded as mistakes. That allows us to say clearly that intervening cause in no way depends on foreseeability or on any other matter having to do with defendant's culpability.

II

Is THERE A METAPHYSICAL RATIONALE FOR THE DOCTRINES OF INTERVENING CAUSATION?

\section{A. Hart and Honoré's Attempt to Avoid Both Policy Constructions and Traditional Metaphysics}

Most of the older literature on causation was content with extracting consistent, usable legal rules of causation from the case decisions. ${ }^{138}$ Very little attempt was made to justify such doctrines either by showing how as artificial constructions of the law they inaximized desirable policies, or by showing how they captured the correct metaphysics of causation (and thereby maximized the policy of achieving retributive or corrective justice).

Hart and Honore's was the first sustained effort to justify the legal doctrines of intervening causation. ${ }^{139} \mathrm{Hart}$ and Honoré were refreshingly clear about eschewing any justification of such doctrines in terms of extrinsic policies (policies, that is, that were extrinsic to the tracking of inoral blameworthiness via some notion of causation that was not of the law's creation). This was to be their inost sustained attempt to roll back the Legal Realists' "functionalist" approach to legal concepts, an approach that sought to construct a meaning for such concepts out of policies like deterrence, efficiency, or unfairness. ${ }^{140}$

Less clear is the relationship of Hart and Honoré's justificatory ambitions to the metaphysics of causation. It is unclear whether they were attemptimg to ground the legal doctrines of causation in (what they saw as) the correct metaphysics of causation; this is mostly because it is unclear what kind of an enterprise they took metaphysics, im general, to be.

In very general terms, their justification of the law's doctrines of intervening causation should be seen in terms of three premises. Premise one: such legal doctrines would be justified if they match the conditions of moral blameworthiness. Premise two: the conditions of moral blameworthiness include causation, in a sense of causation that is not a creation

138. See the extensive case summaries in Beale, Proximate Consequences, supra note 7; Carpenter, Proximate Cause, supra note 12; Carpenter, Workable Rules, supra note 12; McLaughlin, supra note 11; Smith, supra note 9; Terry, supra note 10.

139. See sources cited supra note 13.

140. See, e.g., Edgerton, supra note 6. On the Legal Realists' functionalist approach gcnerally, see Felix S. Cohen, Transcendental Nonsense and the Functional Approach, 35 Colum. L. Rev. 809 (1935). 
either of law or of morality. Premise three: this prelegal, premoral notion of causation is the plain man's concept to be found in unselfconscious usages of "cause" and cognate terms in ordinary language.

Premise one strikes me as being entirely correct. It states no more than what I said in the introduction: The policy to maximize in criminal law is retributive justice, and the policy to maximize in tort and contract law is corrective justice. These forms of justice require legal liability to track closely moral blameworthiness. ${ }^{141}$

Premise two is likewise true. Causing the results one has culpably attempted to cause, foreseen to occur, or unreasonably risked, is more blameworthy than unerely trying, foreseeing, or unreasonably risking when the events in question do not materialize. In short, causation matters to morality, and because it matters to morality, it matters to the law. ${ }^{142}$

It is premise three that is the troublemaker. Suppose that Hart and Honore were right about their claim of what the "plain man" thinks; he thinks that causes are either voluntary human actions or abnormal natural events that are necessary elements coinpleting a set of elements sufficient for the effect, so long as no other such event intervenes between the first and that effect. ${ }^{143}$ Why would this sociological truth justify legal doctrines in accord with such common sense views of "cause"?

Reacting apparently to a sense that theirs was a very conventional approach to issues like causation, Hart and Honoré in the 1985 Preface to the second edition of their book urged that "it is the ordinary man's conception of cause that is used by the law"; therefore, to understand "the structure of ordinary causal statements was and is an indispensable first step towards understanding the use of causal notions in the law."144 Yet as thus far stated, this is just more sociology. The justificatory question, "Why should the law look to the ordinary man's conception of cause?" is untouched by such sociology.

One might urge that what the ordinary person thinks about moral responsibility cannot be wrong, because morality is simply what most people in a given culture think it is. The plain man's view of the elements of inoral responsibility like causation then becones quite relevant because such elements, like responsibility itself, are constituted by the conventions of moral thought. It is pretty clear that neither Hart nor Honoré ever subscribed to this relativistic defense of their approach to causation. ${ }^{145}$ Nor,

141. See MoORE, supra note 27.

142. See id. at 191-247.

143. See supra text accompanying notes $59-100$.

144. HART \& HoNORÉ, CaUSATION (2d ed.), supra note 13, at Xxxiv.

145. See H.L.A. Hart, Morality and Reality, N.Y. Rev. Books, Mar. 9, 1978, at 35 (reviewing Gilbert Harman, The NatUre of Morality: AN INTROduction to Ethics (1977) and J.L. MACKIE, ETHICS: INVENTING Right AND WRONG (1977)). 
incidentally, would it be a defensible approach, given the well-charted and crippling defects of any relativistic metaethics. ${ }^{146}$

Closer to home is the assumption that commonsense views of causation, as revealed by ordinary usage of words like "cause," is all there is or can be to causation, the thing. The ordinary-language philosophy program (in which Hart and Honoré were steeped when writing of causation) often justified its attention to ordinary usage by making three claims, the first of which was that the meaning of words in natural language was to be found in their ordmary uses. ${ }^{147}$ Second, the movement claimed that in finding the meaning in usage, one was looking for word/word relationships, not word/thing relationships. That is, one found the meaning of a word like "cause" by seeing how it was related (by relations of sense and pragmatic appropriateness) to other words like "consequence," "explanation," and the like. Third, that once one discovered the meaning of words like "cause" in this way, one also discovered all there was to be discovered about the thing, causation. To know what "cause" means is to know what cause is. ${ }^{148}$

If one accepts this 1950s ordinary-language philosophy program, then Hart and Honoré's sociology becomes highly relevant to the justification of legal doctrine. For if legal liability tracks moral responsibility, if moral responsibility tracks causal responsibility, and if causal responsibility is fully determined by ordinary thinking about it, then Hart and Honore had all the justification they needed to rely on the plain man's view of causation.

Yet few today would subscribe to the idea that the thing, causation, has no nature save that reflected in ordinary usage of the word, "causation." 149 Imagine a similar claim made about other natural kinds or relations, like water, gold, proton-donor, heat, or dreams. Such a claim cuts off the possibility of further scientific insight about the nature of such things; for if all there is to such things is what is ordinarily known, as reflected in ordinary usage, then scientific hypotheses about kinetic energy, subatomic structure, rapid eye movements, molecular structure, and brain functioning are about something other than heat, protons, dreams, or water.

The alternative view in semantics is that we literally mean more than we know when we use words like "cause." ${ }^{\text {"150 }}$ We intend to refer to a thing,

146. See, e.g., Heidi Margaret Hurd, Relativistic Jurisprudence: Skepticism Founded on Confusion, 61 S. CAL. L. REv. 1417 (1988).

147. In a cryptic aphorism typical of Wittgenstein: "Meaning is use." LudW1G WiTtGenstein, Philosophical Investigations 20 (G.E.M. Anscombe trans., 3d ed. 1958).

148. To dredge up another 1950s saying: "the material mode and the semantic mode are really just two different ways of talking." On the generally antimetaphysical stance of ordinary language philosophy, see Michael S. Moore, The Interpretive Turn in Modern Theory: A Turn for the Worse?, 41 Stan. L. Rev. 871, 927-34 (1989).

149. See id.

150. See Hilary Putnam, Mind, Language, and Reality $215-71$ (1975). See generally Michael S. Moore, A Natural Law Theory of Interpretation, 58 S. CAL. L. REv. 277 (1985). 
whatever its nature might turn out to be. Such a semantics reverses the priority between word/word relations and word/thing relations posited by ordinary language philosophy. Far from the relation of "cause" to other words determining fully what causation is, on the newer semantics what causation is determines the meaning of "cause." The nature of causation"what causation is"-is a matter of fact, inviting theoretical speculation. Such nature is not fixed by the conventions that have hitherto governed idiomatic English usage of the word, "cause."

Once we see the possibility that the nature of causation may differ significantly from the ordinary usage of "cause" by the ordinary person, the need for justification for relying on the common sense concept looms large. For on the moral views that justify the legal doctrines of causation, the law cares about causation only because morality cares about causation. Yet such morality doesn't assign responsibility according to the common man's conception of cause; rather, it assigns responsibility to defendants who actually cause some harm. The nature of the causal responsibility that grounds both moral responsibility and legal liability could be considerably different than that revealed by ordinary usage of "cause."

This general objection to Hart and Honoré's ordinary language approach to justifying the legal doctrines of causation applies with full force to their more particular application of the method to explain and justify intervening causation in the law. The justification they offer for why the law should regard voluntary human actions and abnormal natural events as breaking off the causal responsibility of earlier actors lies in their use of the old "paradigm case argunient" of Oxford-style ordinary language philosophy. ${ }^{151}$ Like David Hunie before them, Hart and Honoré believed that we (collectively and individually) learn of the existence of something called causation by our ability to nuanipulate objects in the world. ${ }^{152}$ We move objects, hit people, twist, push, bend things. Our central paradigm case of causing is doing these simple actions with our bodies. We then analogize from simple doings to more complex manipulations; by doing one thing we can cause something nore renote to occur. ${ }^{153}$

The embryonic notion of cause that we construct fron these simple action paradigms and their first analogical extension is that causation "is an interference in the natural course of events which makes a difference in the ways these develop... The notion, that a cause is essentially something which interferes with or intervenes in the course of events which would

151. For an introduction to paradigm case argument ("PCA") semantics, see Michael S. Moore, The Semantics of Judging, 54 S. CAL. L. REv. 151, 281-92 (1981). Others besides Hart and Honore adopted PCA semantics in their approach to causation. See John Borgo, Causal Paradigms in Tort Law, 8 J. Legal STud. 419 (1979); Richard A. Epstein, A Theory of Strict Liability, 2 J. Legal STud. 151 (1973).

152. See Hart \& HonorE, Causation (2d ed.), supra note 13, at 28.

153. See id. at 28-29. 
normally take place, is central to the common-sense concept of cause."154 With this embryonic concept of cause under our belts, we then analogize further: Natural events, even when there is no human manipulation, may also be causes. In such cases, "the cause, though not a literal intervention, is a difference from the normal course which accounts for the difference in the outcome." 155 And from here, we analogize even further, to include states as well as events, omissions as well as actions, in the kinds of things that can be causes. ${ }^{156}$

It is because voluntary human actions are our basic, central paradigms of causation that we trace causal chains to such actions. ${ }^{157}$ Moreover, it is because of their paradigmatic status that we refuse to trace causal relations through such actions. Where another voluntary human action subsequently intervenes, we lose our ability to analogize the more complex causings to the paradigmatic and simpler doings. ${ }^{158} \mathrm{We}$ cannot so analogize our indirect manipulations to simpler cases of direct action because another, more paradigmatic cause has intervened. "The intervenor did it" precludes us from analogically extending "the original actor did it" to "the original actor caused it."

The same is true for abnormal natural events. These are already at a level of secondary analogy to the paradigm cases of causation, that of simple human actions. When some subsequent event intervenes, it is closer to the paradigm case of causation than is the original abnormal event. Therefore, it too breaks our ability to analogize the first abnormal event to the paradigm case of causation. ${ }^{159}$

One has to understand the general nature of the paradigm case argument to appreciate the justificatory power Hart and Honoré were seeking with the foregoing tale of how we developed our common sense concept of causation. Believers in the paradigm case argument in the 1950s believed that the meaning of words like "cause" was to be found in the paradigmatic exemplars of such words shared by some linguistic community. ${ }^{160}$ Sensible use of words such as "vehicle," for example, depended on speaker and listeners both regarding blue 1958 Buicks as paradigmatic vehicles; skateboards, baby carriages, and bicycles might be vehicles too, but only by analogy to the paradigm case. ${ }^{161}$

154. Id. at 29.

155. Id.

156. See id. at 31 .

157. See id. at $41-44$.

158. See id. at 73.

159. See id. at 77.

160. See, e.g., J.O. Urmson, Some Questions Concerning Validity, in Essays IN CONCEPTUAL ANALYSIS (Antony Flew ed., 1960).

161. This example is Herbert Hart's in his justly celebrated debate with Lon Fuller. See H.L.A. Hart, Positivism and the Separation of Law and Morals, 71 HARv. L. REv. 593, 607 (1958). 
To find the paradigmatic application of a word like "cause" was to find a connection that could not be questioned. Such a connection was "true-by-convention." Anyone who questioned whether a blue Buick was a vehicle simply revealed that he did not know the meaning of "vehicle." Paradigms of words like "vehicle" or "cause" were necessarily mstances of their respective labels, because they were what fixed the meaning of such words. And like the ordinary-language progran in general, so here: things or relations like causation had no nature save that given by their paradigmatic exemplification and analogical extensions thereof. Meaning (as paradigms plus analogies) totally fixed nature, rather than vice versa.

So if Hart and Honore were right about the paradigms for causation, they would (according to the paradigm case argument) have shown us all that need be shown to justify the legal doctrines of intervening causation. Where there are interveming voluntary human actions or abnormal events, the analogy to the paradigm case of causation (simple doings) is broken, and to break the analogy is to show that no causal relation exists.

The inain problem both with the paradigm case arguinent in general, and with Hart and Honoré's use of it here, is the main problem with all of ordmary language philosophy: It allows the nature of the thing, causation, to be fixed by the conventions of present usage (in this case, the paradigms and analogies). It thus purports to cut off scientific theorizing about such nature on the grounds that anything ordinary thought doesn't already recognize as causation can't be causation. ${ }^{162}$

There are many other problems with the paradigm case argument, both in general and in Hart and Honoré's hands. It is doubtful, for exanuple, that people actually possess paradigms for very many of the words they use. Do you really have a standard instance of "vehicle" that you use to judge all other items by analogy? If you do, is the paradigm of vehicle for you the same thing as is the paradigm for others, in the way that the standard instance of "meter" is the iridium bar kept in the Bureau of Weights and Measures in Paris? Thirdly, it is bizarre to think that we possess any abilities to reason by primitive analogy to any paradigms that we do possess in common. Recall Potter Stewart being hooted out of accepting Nixon's offer of the chief justiceship ${ }^{163}$ by his claim that he knew pornography when he saw it even though he could not define it. ${ }^{164} \mathrm{We}$ in fact have no magical abilities to sense "innate similarity spacings," nor is there any clear meaning to be given to any primitive notion of similarity.

The upshot of these last objections is that we should put aside the paradigm case approach to describing our common sense conception of cause. The upshot more generally is that Hart and Honore-or we-should

162. See generally MOORE, supra note 30; MOORE, supra note 27.

163. See Bob Woodward \& Carl Bernstein, The Brethren 15-16 (1979).

164. Jacobellis v. Ohio, 378 U.S. 184, 197 (1961) (Stewart, J., concurring). 
be interested in the common sense conception of cause itself only if we believe that conception to be accurate. Does the best theory of what the causal relation really is include the features so prominent in ordinary thought: the power of voluntary human acts and abnormal natural events to break the chains of causation? That is the question requiring an answer, an answer that can be found only in the metaphysics of causation, not in ordinary usage of "cause" and certainly not in supposed paradigms guiding such usage.

\section{B. The Metaphysics of the Stone Age}

Once we see the need for a metaphysics of causation to justify the legal doctrines of causation, and once we see that the common sense conception of causation does not foreclose or answer the metaphysical inquiry into the nature of causation, then we can appreciate the danger of relying heavily on common sense and ordinary usage. As J.L. Austin recognized, ordinary usage may not prescind from metaphysics as much as it naively engages in it. In Austin's colorful phrase, the worry is that ordinary thought may merely enshrine a naive metaphysics, the "metaphysics of the Stone Age." 165

The Stone Age metaphysics suggested by the legal doctrine of intervening causation, and by the common sense conception of cause underlying such doctrine, seems to go like this. As a bumper sticker common in the 1990s had it: "Shit Happens." Sometimes, even at the macro level, events just go one way rather than another. Inexplicably, lightning strikes one person dead but leaves all others around him alive, or inexplicably, an evil impulse leads one person to kill another deliberately for no reason and with no cause. When such inexplicable coincidences or evil impulses intervene, they break the causal relations that would otherwise govern subsequent events.

The worry about intervening causation in the law is that such Stone Age (New Age?) metaphysics is about all there is to it. One might throw in a little theism-whatever science can't explain, God does. This could help. If there is any uncaused cause in the universe, it would be God. If She deigns to jump into human affairs occasionally-say by tossing down a lightning bolt every once in a while, or allowing the Devil to do some ungodly brainwashing on human beings just to keep the contest interesting-that would explain fresh causal starts. Yet such theism is even more primitive than the brute inexplicability of certain events that it was designed to replace. It is not for nothing that such anthropomorphism is called "primitive animisim," primitive because it so naively assumes that

165. J.L. Austin, A Plea for Excuses, 57 Proc. ARISTotelian Soc'y A 11 (1957), reprinted in FREEDOM AND RESPONSIBILITY 6, 10 (Herbert Morris ed., 1961). 
we can explain natural phenomena like gravitational attraction in terms appropriate to persons, such as love.

In fact, if we alternatively theorize such Stone Age approaches, we may find more serious candidates for a metaphysics that could rationalize the law of intervening causation. My own theoretical reconstruction follows, organized partly around the three sorts of intervening causes in the law (preemptive events, voluntary human actions, and abnormal natural events), and partly around different metaphysical accounts common to all.

\section{An Opening Wedge: Preemptive Intervening Causes}

The easiest sort of intervening cause for which to discover a plausible metaphysical basis is those subsequently arising, "sufficient" events that preempt the ability of the defendant's action to have caused some harm. ${ }^{166}$ For what underlies the law and ordinary thought in such cases is pretty close to the surface.

We first need to rid ourselves of the obscuring talk of "sufficient" conditions. "Sufficient" is one of those context-sensitive words that depends so heavily on factors of particular application as to be useless as a general criterion. In this it is similar to the notion of "sameness." When we say that one thing is "the same" as another-and we inean qualitative, not numerical, identity - we never inean that the two things literally share all of the sane properties. We always contextualize our judgnients of sameness, so that we mean, implicitly, "the same in these (relevant) respects."

Similarly with "sufficient," when we say, "X is sufficient for $Y$," we never inean, "X is sufficient all by itself," for we know that many other conditions must be present or must be absent in order for $X$ to produce $Y$. A spark is not sufficient for an explosion, because oxygen and fuel are necessary as well. These three together are not sufficient for the explosion because the absence of large amounts of inert material is also required. And so on.

True, in the overdetermination cases of the preemptive kind, we can say that the fire that arrived first was sufficient, but it is also true that relative to a different set of things considered, it was not sufficient (and neither was some set of conditions of which the fire was a necessary element). What we are getting at when we call the first fire to arrive "sufficient" is that the second fire to arrive was not necessary. And what we are really getting at in saying both of these things is that the second fire did not cause the damage - the first one did.

"Sufficiency" thus does not explain the causal conclusions in the preemptive overdetermination cases; it merely redescribes those conclusions, and, moreover, does so in a less clear way. What is really going on in the

166. See supra text accompanying notes 100-111. 
preemptive overdetermination cases is that there are two causal processes at work whose nature we know well enough to know that one process was completed (the first fire) while the second was not (the second fire). ${ }^{167} \mathrm{We}$ know enough about how poisons and burns work to cause death, and we know enough about how gunshots or blows to the head work to cause death, that, when we see cases like those earlier described, ${ }^{168}$ we know that a particular victim was shot to death, not poisoned to death, or bludgeoned to death, not burned to death.

Indeed, once we rid ourselves of the unhelpful notion of sufficiency, we can also see that there is nothing unique, interesting, or especially problematic about preemptive overdetermination cases. Whenever we know enough of the underlying causal mechanism at work in a given case, we often see that one cause preempts some other factor from doing what it otherwise would have done. Consider the case where the victim dies from loss of blood; he is shot once by each of three defendants, and loses blood from all three wounds. Each defendant has caused the death, and this is true irrespective of whether: (1) each wound was sufficient to cause death by itself, so that no individual wound was necessary (but the three were jointly necessary); ${ }^{169}$ (2) each wound was necessary by itself, so that no individual wound was sufficient (but the three were jointly sufficient); ${ }^{170}$ or (3) no wound was either individually necessary or individually sufficient, but any two of the wounds was both jointly necessary and jointly sufficient. ${ }^{171}$ We know each defendant caused the death because we know the causal mechanism connecting each of the defendants' action to the death. In the colorful language of the California Supreme Court in a related sort of case, "Drop by drop the life current went out from both wounds, and at the very instant of death the [earlier] gunshot wound was contributing to the event."172

Contrast my three variations of concurrent-cause cases above with a parallel case of preemptive causation: As before, the victim dies of loss of blood; as before, each defendant shot the victim; but here, only one wound

167. Douglas Ehring too finds the preemptive overdetermination cases to be crucial to understanding causation; he also sees the metaphysies involved in such cases, namely, a mechanistic metaphysics capable of carrying eausal influence across discrete sets of processes. See Douglas Ehring, Causation and Persistence: A Theory of Causation 50-70 (1997).

168. See supra text accompanying notes $105,109$.

169. Standardly called an overdetermination concurrent cause case. See Moore, supra note 2, at 10.

170. What I have called the "garden variety concurrent cause case." Id.

171. What I have called the intermediate kind of concurrent cause case, intermediate between the overdetermination and the garden varieties. See id. at 9-10 n.40.

172. People v. Lewis, 57 P. 470 (Cal. 1899). Lewis is actually yet another variant, because the later knife wound caused a much greater blood loss than the earlier gunshot wound. I have elsewhere dubbed these "asymmetrical overdetermination concurrent cause cases." Moore, supra note 2, at 10. Lewis is nonetheless usably like the case deseribed in the text because the larger knife wound in Lewis was not relevantly different (in blood loss) than two smaller gunshot wounds in my variation. 
caused any bleeding, external or internal. If the victim dies of loss of blood, the cause of death is the wound whose effects can be traced to the death through the loss of blood; the other two actions lack this causal mechanism and are not causes of death. They are "preempted" from doing their causal work, assuming they would eventually have killed the victim by some other mechanical process, such as organ failure or blood poisoning.

The preemption cases should be our model for a successful metaphysical underpinning for the law of intervening causation generally. In the preemption cases we bring to bear our detailed knowledge of the physical world in justifying the causal conclusion reached by the law. There is no very general metaphysical truth being relied upon in such cases-save perhaps the truths that nothing can cause an event or state to occur that has already occurred, and that merely hypothetical events that might have occurred but which did not occur cannot cause anything else to occur. Yet the inetaphysical underpinning of the law is nonetheless quite secure in such cases. Our best scientific theories show us that there is no causal relation in such cases, and the moral and legal conclusions tag along behind such metaphysics unproblematically.

I turn now to the other two kinds of intervening causes-voluntary human actions and abnornal natural events-to see whether some equally respectable metaphysics can be found that could justify these legal doctrines as well.

\section{Causation and Explanation}

There is a highly regarded tradition in the metaphysics of causation that follows the general limes propounded by David Hume. ${ }^{173}$ The tradition recognizes that in ordinary speech we employ two quite different causal locutions. First, we cite a particular event as the cause of some other and later particular event, as in, "The spark caused the fire." Second, we explain soine type of event by the occurrence of some other type of event, as in, "Sparks cause fires." The former are called singular causal statements, the latter, statements of causal laws.

Hunne proclaimed ordinary speech to be misleading in this regard. In particular, he urged that the existence of singular causal relations was an illusion. All that could be meant when we say, "c caused $e$," is: There was an event $c$, there was another event $e, e$ did not precede $c$ temporally, $c$ is an instantiation of some type $\mathrm{C}$ and $e$ is an instantiation of some type $\mathrm{E}$, where $\mathrm{C}$ and $\mathrm{E}$ are connected by a $\mathrm{C} / \mathrm{E}$ law, and the $\mathrm{C} / \mathrm{E}$ law amounts to no

173. I am unconcerned with whether the theory sketched in the text was really believed by Hume. On this, see, for example, Galen Strawson, The Secret Connexion: Causation, Realism, and DAvid Hume (1989); BARry Stroud, Hume 42-95 (1977). The Humean theory is an interesting and influential one even if it turns out that Hume never held it. 
more than the regular following of events of type $\mathrm{C}$ by events of type $\mathrm{E}$. More recent variation of this tradition follows Hume in all of this, save the regularity view of causal laws. "Neo-Humeans" regard causal laws as primitive relations between universals, ${ }^{174}$ and probability theorists regard causal laws as irreducibly probabilistic rather than exceptionless universal generalizations. ${ }^{175}$

Hume's regularity theory, the theory of the neo-Humeans, and the probability theory together make up the generalist approach to causation. For all three branches of the Humean tradition reduce singular causal statements to statements of causal laws. Thus, some particular event $c$ cannot be a cause of $e$, unless $c$ and $e$ are instances of some C/E law, however construed. This reductiomst metaphysical view of causation gives rise to two sorts of accounts of the law's notion of an intervening cause, both having some basis in Hart and Honoré's writings.

\section{There Are Natural End Points to Explanations in Term of Causal Laws}

Hart and Honoré's essential idea here is that causal explanations come to an end. ${ }^{176}$ When we ask, "What caused the fire?" we are satisfied with the answer, "an arsonist." We do not need or want further explanations, like a history of the arsonist's unhappy childhood, his need for money from fire insurance, and the causes of that, and so on. Where no further explanation is appropriate no statement of singular causal relations is appropriate either (for remember, on this view, singular causal statements are just disguised explanations in terms of causal laws). Thus any event that occurs before the event that is the subject of a satisfying causal explanation drops into the background as a mere condition, not in any sense a cause, of the event being explained.

To complete this line of thought, Hart and Honore then urged that there were two sorts of satisfying causal explanations, those that stopped at voluntary human actions and those that stopped at unusual natural events. ${ }^{177}$ When seeking an explanation for events like harms to victims, we search among the conditions necessary for such harms until we find one of these two types of items, and, when we find one, we search no further back in time for any other such iteins as may have preceded the item we already found.

There is no doubt that Hart and Honore captured important features of our explanatory practices. In seeking an explanation, for example, of why the Spanish Armada was defeated, we are most interested in voluntary actions like Drake's decision to take advantage of the rather stupid Spanish

174. See, e.g., D.M. ARMSTrong, What Is A LAW OF NATURE? (1983).

175. See, e.g., PATrick Suppes, A Probabilistic Theory of Causality (1970).

176. See HART \& HonORÉ, CAUSATION (2d ed.), supra note 13, at 32-44.

177. See id. 
decision to arrange their ships in the shape of a giant bird (pleasing to God in Heaven, no doubt, but exposed to concentrated fire at the tips of the wings). Add to this the great storm in the North Sea that dispatched a number of the ships that escaped Drake's fire, and we may well end up satisfied that we understand why the Spanish Armada was defeated ... so satisfied, indeed, that we look no further for earlier "underlying" or "root" causes.

Yet even on the generalist accounts of the Humean tradition, this surely will not do to account for the causal breaks posited by the legal doctrines of intervening causation. That is, even granting Hume's reductionist premise-no explanation, no causal relation-there surely is an explanation behind the decisions of Drake and of the Spanish, and behind the great storm. There just is no explanation in which we are much interested, given that our curiosity began with the defeat of the Armada. And surely our interest, or the lack of it, cannot determine whether the decisions of Drake and the Spanish, or the North Sea storm, were caused. ${ }^{178}$ If we were to take any other view, no tree would fall in the proverbial forest so long as we had no interest in hearing about it.

\section{There Are Literally Inexplicable Events}

So Hart and Honoré needed a more radical use of Hume's reductionist metaphysics here. They needed to say (what they in fact came close to saying at times) that soine events are truly inexplicable. What makes for an abnormal conjunction of natural events, for example, is just the lack of any causal law connecting the two types of events in question; what makes for an extraordinary natural event tout court is just the lack of any (ordinary) causal law explaining or predicting it. What inakes for a fully voluntary human action is that there are no causal laws explaining or predicting such action. And now one could put Hume's reductionist metaphysics to good use: Such niexplicable events are literally uncaused events, so that there are no causes of then that could be looked to to explain the harm they themselves cause.

Yet are "acts of God," coincidences, and "free" huinan choices in fact inexplicable by causal laws? Consider first voluntary human actions. In the philosophy of social science generally, ${ }^{179}$ and in the philosophy of history

178. For another example of this line of criticism of Hart and Honore, see MACKIE, supra note 108 , at 120 (explaining that while our interests determine what is satisfying by way of an explanation, such interests are irrelevant to a theoretical account of causation which does not distinguish cause from conditions). Hart and Honoré reject Mackie's interest-relative rejection of the cause/condition distinction as being only pragmatic and not truly causal. See HaRT \& HonorE, Causation (2d ed.), supra note 13, at xxxix. Yet it is very unclear how their own line of argument here is or can be anything other than "merely pragmatic."

179. See CARL G. Hempel, Aspects of Scientific Explanation, in AsPects of ScIENTIFIC EXPlanation 331 (1965); The Nature and Scope of Social Science (Leonard I. Krimerman ed., 1969). 
more particularly, ${ }^{180}$ there is a respectable body of opinion holding that human behavior is not subject to "covering laws." It is notoriously difficult to frame universal causal laws about human behavior, because what people do and why they do such things seems too variable to be captured by such laws. People just are not as boringly repetitive as protons. For such reasons, Hart and Honoré distinguished the seeming causation of voluntary human action as in reality noncausal in any central sense:

Relationships between two persons' actions ... do not depend upon "regular connections" or sequence as the causal relations between physical events do. Hence the assertion that one person, for example, induced another to act is not "covertly" general ... [G]eneralizations have a place here but a less central one. ${ }^{181}$

Yet surely one could grant all of this, and still protest: First, at the macro level, there are at least probabilistic laws. Hume himself gave a good example: Leave a purse of gold at Charing Cross in London and come back an hour later; it probably will not be there because probably someone will pick it up. ${ }^{182}$ Second, as we leave the macro level for the micro events making up human behavior and motivation, neo-Humeans like J.L. Mackie have urged that we will find universal "laws of working" connecting stages in what at the macro level we call a single action. ${ }^{183}$ That we do not know such micro laws of working reflect only our empirical ignorance; it does not reflect any brute inexplicability to human choice.

In dealing with the obvious fact that many human choices can indeed be explained, Hart and Honoré relied on a view quite prevalent in the ordinary language philosophy of the $1950 \mathrm{~s} .{ }^{184}$ This was the view that uncompelled human choices were explicable by reasons, not by causes; that only when choices were compelled was it appropriate to speak of them as caused; ${ }^{185}$ that it was thus a category mistake to speak of caused but

180. Compare CARL G. HeMPel, The Function of General Laws in History, in AsPects of SCIENTIFIC EXPLANATION, supra note 179, at 231, and Carl G. Hempel, Reasons and Covering Laws in Historical Explanation, in PHILosopHY AND HistoRy 143 (Sidney Hook ed., 1963), with William Dray, The Historical Explanation of Action Reconsidered, in PHILOSOPHY AND HISTORY, supra, at 1050.

181. HaRt \& Honork, Causation (2d ed.), supra note 13, at 51-52; see also Harton v. Forest City Tel. Co., 59 S.E. 1022, 1026 (N.C. 1907) ("The spontaneous action of an independent will is neither the subject of regular, natural sequence, nor of accurate precalculation by us."); Kadish, Causation and Complicity, supra note 14, at 163 ("[E]very volitional actor is a wild card; he need never act in a certain way... . No laws of nature can settle the issue.").

182. See David Hume, EnQuiry CoNCERning the Human Understanding 93 (Clarendon ed. 1902).

183. MACKIE, supra note 108, at 120-25, 210-12.

184. See A.R. Louch, Explanation and Human Action (1966); A.I. Melden, Free Action (1961); Richard Peters, The Concept of Motivation (1958); Peter Winch, The Idea of a SOCIAL SCIENCE (1958). For Tony Honore's sympathetic use of this old distinction, see Honoré, supra note 13 , at $382-84$.

185. See Hart \& Honore, supra note 13, at 80 ("When we do speak of a human action as caused, this is with the strong implication that the agent acted in one or more of those many different 
voluntary choices, the mistake of explaining something in one category (free choices) by something in a different category (causation). ${ }^{186}$

The main problem with this old view, like all variants of the category mistake argument, was that no amount of regimentation of ordinary speech into categories could seal off the insights of an advancing science. In particular, it has become clear that "reasons"-belief/desire sets of a certain content-are as much causal of behavior as is anything in the natural world. ${ }^{187}$ What sense are we to assign to the "because" in sentences of the form, "He did it because he wanted the money," if it is not the usual causal sense? It is thus difficult today to take very seriously the claim that the only way to explain free human choices is by resort to the language of "reasons" instead of "causes."

This more radical use of Hume fares no better if we move from voluntary human choices to abnormal natural events. After all, the "shit happens" view of coincidences is pretty naive. As Hart and Honoré caine to recognize, ${ }^{188}$ even if there are no general causal laws connecting speeding in an automobile, for example, and a tree falling, surely there are Mackie's micro laws of working connecting successive stages of this larger conjunction and making the conjunction fully explicable. If we do not pursue such micro laws of working here any more than we do for human behavior, that is only because of our limited explanatory interests. It is not because there are no such explanations (and thus, on this view, no such chain of causes goimg back to defendant's action).

The probabilist branch of the Humean tradition about causation has tried to salvage things here. ${ }^{189}$ Adherents of this view note, correctly, that in cases of coincidence, the conditional probability of the victim's harm, given the defendant's action, is very low. They also note that the intervening event dramatically increases that probability. If one identifies singular causal relations with probabilistic laws-which is the probabilistic theory of causation in a nutshell-then the intervening event is a much bigger cause than even the defendant's original action. On a kind of de minimis principle one might thus relegate defendant's action to the status of a noncausal event, given that its contribution was below some threshold of significance.

circumstances which are treated as inconsistent with his action being fully voluntary: we imply if we speak of an action as 'caused' that the agent acted under coercion or domination or that he had lost self control or was submitted to some special stress or emergency .... If it turns out that there were no such special circumstances the natural conclusion would be that nothing caused him to [so act]: he just deliberately did so.").

186. See Gilbert Ryle, The Concept of Mind 11-24 (1949).

187. See Donald Davidson, Actions, Reasons, and Causes, in Essays on Actrons and Events 3 (1980).

188. See Hart \& Honore, Causation (2d ed.), supra note 13, at xxxix.

189. See Peter Lipton, Causation Outside the Law, in JuRISPRudence: Cambridge Essays 143 (Hyman Gross \& Ross Harrison eds., 1992). 
One problem with this view is the implausibility of the probabilistic theory of causation. One cannot simply identify causation with an increase in conditional probability, at least not without encountering obvious counterexamples. For example, epiphenomena: It appears that some common cause $C$ at $t_{1}$ causes men to develop pattern baldness $B$ at $t_{2}$ and heart attacks $H$ at $t_{3}$. No one thinks that baldness causes heart attacks. Yet the conditional probability of $H$ given $B$ is higher than the probability of $H$ alone; so on a simple-minded probabilities theory, baldness does cause heart attacks. Probability theorists must thus propound theories of causation of much greater sophistication if they are to avoid such obvious problems. ${ }^{190}$

A second problem lies in the seeming overinclusiveness of the suggested account of intervening causes. Surely it is not just extraordinary winds that dramatically increase the risk of a fire spreading; normal evening breezes that resuscitate a fire about to go out dramatically increase the conditional probability of fire damage as well. Similarly, it is not just intervening voluntary action that can dramatically increase the probability of some harm; a coerced gun shot can be just as deadly as a freely chosen gun shot. The probability account thus seems to make far too many events into intervening causes, and it seems blind to the criteria of intervening causation.

\section{E. Libertarian Metaphysics for Human Choices and Acts of God}

Surely at the root of many people's intuitions about uncoerced human actions breaking causal chains is a libertarian metaphysics. On this view, voluntary human choices are literally uncaused events. They are thus fresh causal starts, relegating all prior events to noncausal status vis-à-vis the chain of events such fresh starts cause.

James McLaughlin early on summarized this metaphysical basis for the law on intervening human actions:

Where human or animal action is purely involuntary so that an instantaneous response is made to the defendant's direct force without the exercise of choice, there is no reason for treating such response as constituting a new or intervening force. Where there is voluntary action or action involving choice on the part of any being other than the defendant, a basis for distinction is apparent .... It may be a field for psychological speculation whether all such actions cannot be resolved completely in terms of physics and chemistry, but it is clear from all legal tradition and analogies that voluntary action must not be regarded as perfectly mechanical. The

190. For a sympathetic attempt to "tech" up the probabilistic theory to deal with epiphenonena, see Wesley C. Salmon, Probabilistic Causality, 61 Pac. PhIL. Q. 50 (1980), reprinted in Causation 137 (Ernest Sosa \& Michael Tooley eds., 1993). 
new element of conscious choice, which is elusive from a mechanical point of view, prevents causation from being direct. ${ }^{191}$

Hart and Honoré similarly attributed a libertarian metaphysics both to the law and to the common sense notions they viewed as undergirding the law. Early on they held that "whatever the metaphysics of the matter may be [a deliberate] human action is never regarded as itself caused or as an effect." 192 In the two editions of their book they softened this line a bit; "in some sense," they thought, a fully voluntary human action could be said to be caused, but not in the central sense of "caused" used by the law to assign responsibility. ${ }^{193}$ This is a kind of metaphysically dualist view about causation. The "central" notion is of a relation that fully determines (is "sufficient" for) that which is caused; the secondary notion is of a relation that only "occasions," "induces," or "inclines" that which it causes. The latter terms are used to connote a lack of determination and sufficiency in this kind of causation. Such lack is but another name for freedom, and so this softened line taken by Hart and Honoré remained libertarian in its metaphysics. ${ }^{194}$

Despite these antecedents, it is mostly Sandy Kadish who has explored the (metaphysically) libertarian roots of intervening-cause doctrine. ${ }^{195}$ Like McLaughlin, Hart, and Honoré, Kadish doesn't tell us his own metaphysical views; rather, he too describes "the beliefs that underlie the criminal law." 196 Central to those beliefs is the idea that "voluntary actions cannot be said to be caused," at least not in the sense that physical events are caused by relentless forces and necessary conditions. ${ }^{197}$ Human actions may be "influenced" by various events, "but influences do not work like wind upon a straw." 198 Rather, humans are total sovereigns over their own actions, ${ }^{199}$ in the sense that, despite the influences of genes and environment, a person is free to choose to act contrary to such influences. ${ }^{200}$

This robustly libertarian metaphysics does allow that some human behavior is caused, and not merely influenced, by prior events. Such behavior is, however, the kind of nonvoluntary behavior so fully explored by Hart and Honoré. Reflex reactions, involuntary motor movements,

191. McLaughlin, supra note 11 , at 168 .

192. Hart \& Honoré, supra note 13, at 80.

193. HART \& HoNORE, CAUSATION (2d ed.), supra note 13, at 42-43, 51-59, 186-204, 363-88.

194. I discuss Antony Flew's expression of this kind of dualisitic determinism in Moore, supra note 27, at 513-14. For two other attempts to articulate a nondeterministic "causation" of human actions, see Alan Donagan, The Theory of Morality 45 (1977); Antony Flew, Psychiatry, Law and Responsibility, 35 PHIL. Q. 425 (1985).

195. See Kadish, Causation and Complicity, supra note 14.

196. Id. at 137.

197. Id.

198. Id. at 141 .

199. See id.

200. See id. 
posthypnotic behavior, acts done under ignorance, duress, natural necessity, provocation, addiction, insanity, infancy, and the like are all less than wholly voluntary because they are less than wholly free. Such less than wholly voluntary behavior is typically excused because in such cases "my freedom to have acted otherwise was totally or partially impaired."201 More pertinently for our purposes, behavior that is the expression of such impaired freedom does not constitute an intervening cause; after all, being totally or partially caused itself, it could not represent a fresh causal start breaking causal chains. Such unfree, nonvoluntary behavior is just another link in the causal chain, no different than other caused events.

Libertarian metaphysics is difficult to sustain, as we shall see. Perhaps for this reason, Kadish and his intellectual antecedents here all refuse to defend libertarian metaphysics as such. Rather, they defend the more modest, sociological claim that "commonsense" (that is, other people) believe in such a metaphysics. Such sociology is fine if one wishes merely to explain why we have the legal doctrines of intervening causation that we do. If our ambitions are to justify such doctrines, however, we need to leave off doing the sociology of other people's metaphysics and start doing our own. Voluntary human actions have to be uncaused-not just believed to be uncaused-if they are justifiably to serve the sort of chain-breaking function they do serve in our law.

There is a hint in McLaughlin of a contrary view, for he seems to think that the law as an autonomous discipline can just posit human freedom even if psychology could show us otherwise. ${ }^{202}$ The hint is developed into an explicit defense of "autonomous legal metaphysics" by later criminal law theoreticians such as Jerome Hall ${ }^{203}$ and Herbert Packer. ${ }^{204}$ On this view, even if science tells us that voluntary human actions are fully caused, the law can presuppose just the opposite if it needs to do so for its own purposes. Such views of legal autonomy ignore the obvious here: If the legal doctrines (such as those of intervening causation) we seek to justify are based on the policy of fitting pumshment to moral desert, and if moral desert itself depends on the facts of causation, then we cannot just posit any old "facts" about causation that we need. ${ }^{205}$ In particular, if the doctrines of intervening causation make sense only if voluntary human action is uncaused, then it will not do just to posit that, for legal purposes, we will assume such behavior is uncaused. For the legal doctrines in question to be justified, we need such behavior to $b e$ uncaused. A fictional freedom here

\footnotetext{
201. Id. at 142 .

202. See McLaughlin, supra note 11 , at 168 (arguing that law must trcat human choiccs as nonmechanical even if psychology shows that they are at bottom fully mechanical).

203. See Jerome Hall, General Principles of Criminal Law 455 (2d ed. 1960).

204. See Herbert Packer, The Limits of The Cruminal Sanction 74-75 (1968).

205. I argue this at greater length in MOORE, supra note 27, at 514-16.
} 
is about as useful as is a fictional can opener to a starving man possessed of only tinned goods. ${ }^{206}$

There are three reasons to reject any libertarian defense of intervening-cause doctrines. One is that it does not account at all for acts of God. Even if human wills are free of being caused, that does not give any support to the doctrines of abnormal natural events and coincidences as intervening causes. Only a theistic view of such natural events can bring thein under the umbrella of a free-will theory of intervening causation. (And even for theists, their God has to be only an occasional intervenor with a taste for the dramatic-He sends only freak winds, not normal evening breezes.)

The second reason to reject any libertarian basis for intervening-cause doctrines stems from the poorness of fit between the metaphysics and the legal doctrines. The legal doctrines, as we have seen in detail, draw the line (of actions constituting intervening causes) at: (1) voluntary (willed) bodily inovement; (2) itself motivated by an intention (or sometimes, accompanied at least by foresight) to do the harm done; (3) which intention or foresight is formed in the absence of coercive pressures making the choice difficult; (4) by one sufficiently possessed of his faculties as to be a generally responsible agent. As we have also seen, ${ }^{207}$ Hart and Honoré treat these conditions as the boundaries drawn by common sense around when an action is truly free in the sense of uncaused. They thus find a good fit between the plausible libertarian metaphysics of "common sense" and the law's doctrines of intervening causation. I, on the contrary, think the fit to be quite poor. ${ }^{208}$

If I were a libertarian about free will (which I anı not), I would draw the line of free versus caused action around items (1) and (4) above. That is, I would argue that what separates persons from all other creatures is their freedom of will; thus, (4) above. Further, I would argue that the immediate locus of the will is on those voluntary bodily movements that are the essence of human actions, and that what makes a mere behavioral routine into a human action is the will that causes such behavior, when such will is itself uncaused. Thus, (1) above.

So far so good for the libertarian defense of intervening-cause doctrine. Yet even as this hypothetical libertarian about the will, I can see no

206. You know the old joke: The economist scornfully puts aside other suggestions about how to open the only can of food on a deserted island, saying that by his science it is easy: "Assume a can opener."

207. See supra text accompanying notes $59-83$.

208. The argument that follows is similar to my earlier argument, see MOORE, supra note 27, at $491-502,523-37$, to the effect that a plausible boundary to when we are free and when we are caused poorly fits our legal doctrines of excuse. Herbert Hart himself came to question the fit between a libertarian metaphysics and the law's doctrines of intervening causation even before the publication of the second edition of Causation in the Law. 
temptation to think that the willed bodily movements of a fully sane, adult human being become unfree if done in ignorance of certain properties of those movements. Consider the facts of Watson ${ }^{209}$ again. Whether Duerr, the intervenor, knew the gas was present when he threw his cigar, and whether he knew that the cigar would ignite the town, doesn't change the fact that he willed the movements that sent the cigar on its way. His act was intentional vis-à-vis the harm only if he had such knowledge, but surely his act was as free in the one case as in the other.

Moreover, on the most plausible mode of individuating actions and other events, Duerr did but one act when he threw the cigar. ${ }^{210}$ There are many ways to refer to that one act, utilizing different types of actions: $\mathrm{He}$ moved his arm, he moved the cigar, he lit the gasoline, and he destroyed the town. If Duerr acted at all-if, that is, he willed the bodily movements that resulted in the cigar touching the gasoline-then necessarily he did certain types of actions intentionally. ${ }^{211}$ If he did not intentionally destroy the town or ignite the gas, he did intentionally move his arm. Are we to imagine that his one act was free under the description, "moved his arm," but caused under the description, "destroyed the town?" That would lead the libertarian to a flat contradiction, namely, the very same act was both free and not-free.

Intention and foresight thus cannot be a line separating caused acts from free ones. Any plausible libertarianism must eschew condition (2) as marking such a boundary. Yet (2) is very much part of the boundary separating those acts that are not intervening causes from those that are. Thus, the charge of lack of fit between the legal doctrines and any plausible libertarian metaphysics.

Things are no better with regard to condition (3). It is true that when a choice becomes difficult because of some threat, natural necessity, overpowering craving, or unhinging emotion, we easily speak of the forces causing us to do what we did. Yet what of those cases where the capacities of the intervening actor remain undisturbed, intact, and fully functioning? Suppose such an actor finds himself at the top of a burning building, the fire having been set by an arsomist; having steeled himself to look death in the face without fear or even excitenient, he coolly decides to jump rather than burn to death. In such cases, Herbert Hart would say, the actor's capacities to decide are intact but his opportunity to use his perfectly functioning capacities is diminished. ${ }^{212}$ Such an actor has an excuse, when his

209. Watson v. Kentucky \& Indiana Bridge \& R.R. Co., 126 S.W. 146 (Ky. 1910).

210. This "coarse-grained" mode of event-individuation is defended in MOoRE, supra note 30, at 280-301.

211. See id. at 146.

212. Hart's well-known account of when we are excused: when we lack capacity or when we are denied opportunity to use such capacity. See Hart, supra note 77. Hart put forward this account of 
own responsibility is at issue, and such an actor's constrained choice is said by the law to be less than fully voluntary and thus not an intervening cause when the arsonist's responsibility for the jumper's death is in question.

I should think that a sensible libertarian would find no temptation to regard such diminished-opportunity choices to be unfree. For in such cases the actor deliberates, decides, and executes his decision as rationally and as deliberately as in cases of greater opportunity. The phenomenology seeins as free as any other case of deliberate choice, yet to fit the doctrines of intervening causation the libertarian would have to conclude that such choices were caused, not free.

Now let me stop pretending to be a libertarian about the will. In truth, I find libertarian metaphysics to border on the unintelligible. The closer one looks at this metaphysical position, the worse it looks. If "common sense" indeed subscribes to such a metaphysics, so much the worse for "common sense." It can be no justification of legal doctrine to be based on error this fundamental, no matter how widely shared such error may be in our populace.

Take the best case for libertarians, situation (1) above, where the will admittedly plays a decisive role in the concept of human action. We act only if we will. The libertarian temptation is based on the idea that willing is necessarily incompatible with causation of the will (but not, of course, with causation of further events by the will).

The will as an uncaused causer is a very strange idea. How can there be an event that causes other events yet is itself not subject to causal influences by earlier events? Aquinas gave this role to God, but are we so divine in all of our actions? To sustain such an odd idea, libertarians usually invent another, even odder idea: The will (that is free) operates in a realm distinct from the realm of ordinary natural events. Ordinary events exist in both space and time, but mental events like willings exist in time only. This is what insulates willings from causal influences. Or so the dualist story goes. (Of course, there is the awkward question of how willings cause events in the natural world, given the insulation of willings within the distinct world of mind.)

Just how odd a story this is should become more apparent the more one thinks hard about what willings are. As we learn more and more about the brain, we are increasingly able to isolate certain brain structures as having some role in the mental act of willing. We know that the supplementary motor area of the cortex is involved in willing bodily

excuses precisely to sidestep any issue of determinism; he saw that one could have capacity and opportunity even when one's choices were fully caused. 
movements. ${ }^{213}$ We know that the brain functionally separates the initiation of motor movement from the regulation of movement once initiated and that this functional division is realized in different areas of the brain. ${ }^{214} \mathrm{We}$ know that in motor-movement initiation there are distinctive patterns of blood flow and electrical energy peculiar to willed (versus involuntary) motor movement. 215

It is very unlikely that such physical events in the brain are uncaused. Therefore, if willings are uncaused ("free"), then they must be distinct from these brain events. Such brain events may be some other, distant event-one might call them "schwillings"- but on this view they could not be willings. ${ }^{216}$ But then, what are willings? Mental events, construed as existing in a special realm, that of the mind, existing in time but not in space, accessible through a special mode of observation known as consciousness. ${ }^{217}$ By such route the libertarian in metaphysics is driven ineluctably towards dualism in metaphysics.

It is much more plausible to think that "willing" refers to a functionally specified state of the brain, a state defined by its mediating and executing role between belief/desire/intention sets, on the one hand, and bodily movements, on the other. ${ }^{218}$ Such a functionally specified state may have many different physical realizations, but in our brains the structural possibilities are far from infinite. Even though we only know part of the functional/structural story about willings, we literally mean more than we know when we speak of "willing." The same is true of other words, like "water," "gold," and "tiger." In all such cases we intend to refer to a kind whose nature is only partially glimpsed. ${ }^{219}$ When scientists tell us more and more about that nature, they are not changing the subject-to "schmater," "schmold," "schwilling." Rather, they are telling us more about what water, gold, and willings are.

Taking this latter functionalist/physicalist view of mental states like willings, there is no reason whatever to think that willings are uncaused. Such functionally specified, physically realized events are both causes and effects of earlier causes, like all other events. They cannot, on such an account, be literal fresh causal starts breaking causal chains wherever they intervene.

213. See Gary Goldberg, Supplementary Motor Area Structure and Function: Review and Hypotheses, 8 Behavioral \& Brain ScI. 567 (1985).

214. See Benjamin Libet, Unconscious Cerebral Initiative and the Role of Conscious Will in Voluntary Action, 8 BeHA vioral \& BRAIN SCI. 529 (1985).

215. See id.

216. For such an ostrich-like reaction to the rapid-eye movement and EEG evidence about dreaming, see Norman Malcolm, Dreaming (1959). For the corrective, see Putnam, supra note 150.

217. On the push of libertarianism to dualism, see RYLE, supra note 186.

218. See MOORE, supra note 30 , at 113-65.

219. See Putnam, supra note 150; Moore, supra note 148. 


\section{F. Intervening Causes as Sufficiently Big Causes as to Relegate Earlier Events to De Minimus Causal Contributors}

Perhaps the most common account of the metaphysics underlying the intervenimg causation doctrines of the law is in terms of "forces." The general idea is that causation is a matter of physical forces acting on one another, and that one force can cut off the operation of another force so as to preclude any causal relation between the latter and some harm. Most of the earlier writers on intervening causation expressed themselves in this way. ${ }^{220}$ Hart and Honore found such talk of "forces" to be too metaphorical to be of any real use. ${ }^{221}$ They rightly noted that writers such as Beale never attempted to translate such ideas of "forces" into usable notions that could be applied to economic losses and other nonmechanical situations.

The continued use of such talk by contemporary legal theorists is not much more metaphysically self-conscious than was that of Beale or of his followers. Richard Epstein holds that "force and dangerous conditions are still the only issues material to the causation question" 222 and fleshes out the notion of a dangerous condition in terms of stored and unstable energy. ${ }^{223}$ An intervening cause for Epstein then becomes a subsequently arising "big" force, while, by contrast, "little forces never break the chain of causation."224 Yet none of this talk of forces and energy is fleshed out by Epstein because of his reliance on paradigms to give the meaning of "cause." As we recall, the paradigm case approach to meaning regards definitions of "cause" to be otiose. ${ }^{225}$

George Fletcher, to pick another contemporary example, willingly admits that his talk of "causal energy" is metaphorical. ${ }^{226}$ Yet such talk by Fletcher is worse than metaphorical or vague; it explicitly mixes in things that could not be aspects of force or energy in any sense. Fletcher supposes a case in which the victim ("Gabe") is negligently injured by defendant ("Jack"). While in the hospital, the intervenor ("Mike") executes Gabe. Fletcher's gives the following account of why Mike's act is an intervening cause:

When Mike enters Gabe's room and lays his hand on his intended victim, he invests more personality, more energy, into the unfolding of causes and events. This greater input of personal force brings his actions into the foreground .... Jack's initial injury of

220. See Beale, Recovery, supra note 7; Beale, Proximate Consequences, supra note 7; Bohlen, supra note 8; Carpenter, Proximate Cause, supra note 12; Carpenter, Workable Rules, supra note 12; Levitt, supra note 12; McLaughlin, supra note 11.

221. See Hart \& Honoré, CAusation (2d ed.), supra note 13 , at $30,96-97,341$.

222. Epstein, supra note 151, at 180.

223. See id. at 177-78.

224. Id. at 183-84.

225. See supra note 151.

226. George P. Fletcher, Basic Concepts of Criminal LAW 66 (1998). 
Gabe is merely negligent .... Jack's contribution at the outset is less substantial and it is overwhelmed by Mike's committed and willful intervention. ${ }^{227}$

It should be apparent that Fletcher is exploiting the vagueness of "energy" in these contexts to smuggle in notions of moral culpability. Because Mike is more culpable than Jack, his causal contribution is said to be greater. Yet as we saw earlier, causation is supposed to be one of the criteria by which we assess moral blameworthiness; if we allow moral culpability to guide our causal judgments, then causation cannot be such a criterion.

Fletcher is not alone in mixing moral blameworthiness with his idea of force and energy. Earlier writers too assumed without argument that intentional intervenors brought more "force" to their interventions than did merely negligent intervenors, even when the physical behavior of each was identical. Without some metaphysical account of how this could be so, this looks for all the world like Fletcher's more explicit use of moral blameworthiness as a criterion of causation (rather than the other way around).

We cannot make complete metaphysical sense of the "forces" translation of intervening causes here, ${ }^{228}$ but perhaps we can at least strip some of the vagueness and metaphor from this approach, as well as rob it of its illicit moral subtext. The way to begin to make sense of the forces approach is in terms of three propositions. The first two are metaphysical, and the third is a distinctively moral doctrine. Proposition one: causation is a scalar relation. ${ }^{229}$ Scalar relations are more-or-less affairs, not matters of black or white. Being "redder than" is a scalar relation because one item can be more red than another. "Dead," by contrast, is an all or nothing quality; one either is or is not dead, so that one person being "more dead" than another makes no sense.

The idea here is that causation is a relation that can vary along a smooth continuum. One event can be more of a cause of some harm than another event, even if both events causally contribute to that harm. If two defendants each strike one victim, who dies of the loss of blood, it seems to

227. Id.

228. For an attempt to cash out the metaphors here, see David Fair, Causation and the Flow of Energy, 14 ERKENNTNIS 219 (1979) (representing a physicalistic reduction of the causal relation to one of energy-momentum transference in the technical uses of the words in physics).

229. I discuss this aspect of causation in Moore, supra note 2, at 13-15. Whether causation is scalar in nature is a disputed matter, particularly by those enamored of necessary or sufficient condition analysis of causation (which tend to be all or nothing analyses). Compare Richard A. Epstein, Defenses and Subsequent Pleas in a System of Strict Liability, 3 J. LEGAL STud. 165 (1974), and Mario J. Rizzo \& Frank S. Arnold, Causal Apportionment in the Law of Torts: An Economic Theory, 80 Colum. L. REv. 1399 (1980), and Smith, supra note 9 (all contemplating degrees of causal contribution), with HART \& HoNork, CAUSATION (2d ed.), supra note 13, at 223, and MACKIE, supra note 108, at 128-29, and John Borgo, supra, note 151, at 448-52 (all questioning the sense of talk of degrees of causal contribution). 
make sense to say that the blow that caused a greater loss of blood was more of a cause of death than the blow that resulted in a smaller loss of blood. Similarly with two fires that join: the bigger fire is more of a cause of the harm than was the smaller fire. Similarly, when a town is flooded by waters, most of which would have flooded the town even if defendant had not negligently damaged the drainage wickets protecting the town, the flood is more of a cause of the damage than is the defendant's action.

Second proposition: the scalarity of causation is specifically such that the causal relation diminishes over time. ${ }^{230}$ This is the famous idea that causation peters out over time, much as the ripples from a stone dropped in a pond diminish as they travel outward. The basic metaphysical picture here is of an inverted cone of causation; every event has multiple causes so that the immediate effect of any given event is itself but one of numerous causes in the production of another event, and so on. At each successive period of time, the causal contribution of any given event diminishes in proportion to the number of other events contributing to the effect in question:

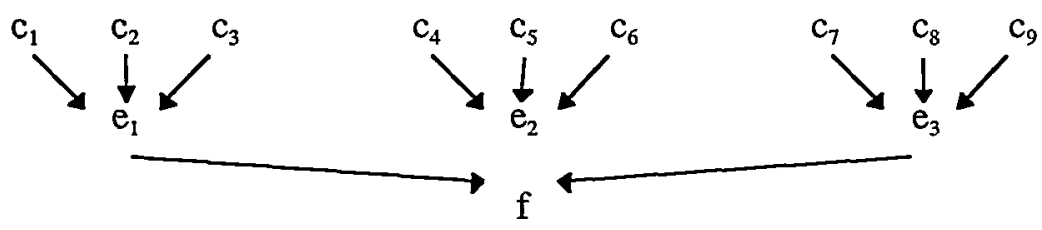

$c_{l}$ may cause $e_{l}$, but its contribution to $f$ (or to events $f$ in turn causes) may be de minimis, on this picture of causal relationships.

Third proposition: the amount of causal contribution needed for an actor to be morally responsible for some harm, is non-de minimis (or "substantial"). ${ }^{231}$ When assessing an actor's blameworthiness, causation of a harm marks the difference between a serious degree of blameworthiness for the harm and a lesser degree of blameworthiness for only risking, foreseeing, or trying to cause, that harm. On the assumption that causation is a matter of degree, morality needs some line drawn on the continuum of possible causal contribution separating causers from mere riskers and attempters. The vague notion of "substantial" is as good a line as we are likely to get. The vagueness of the idea of substantiality is not a defect but a virtue. As Aristotle remarked long ago, we should not demand greater precision than a subject matter can bear. ${ }^{232}$ This is particularly true of attenipting to

230. See generally Moore, supra note 2, at 15-17.

231. The moral premise of Jeremiah Smith's (and the Restatement of Torts's) "substantial factor" test. See Smith, supra note 9.

232. See ARIstotle, Nicomachean Ethics, bk. I, ch. 3, 347-48 (Richard McKeon ed., University of Chicago Press 1973). 
quantify exactly where a line is to be drawn on a smooth continuum. We can stipulate that the difference between a city and a town is at 50,000 inhabitants; but to do so usually hinders, not helps, our use of the terms defmed, as in generalizing, "living in cities leads to higher levels of anxiety than living in towns."233 Mutatis mutandis for precise definitions of substantial degrees of causal contribution.

Assent to these three proposition allows one to see why the subsequent, preeinptive cause cases are our clearest examples of intervening causation. In the hypothetical case where one defendant poisons the victim and an intervenor subsequently shoots the victim dead, ${ }^{234}$ we know that the poison did not get the chance to do its work in causing death, so its degree of causal contribution was zero. This is the clearest case of de uminimis or insubstantial causal contribution. Alinost as easy are the cases where the intervening cause is a vis major, or "act of God." Gale-force winds, unprecedented floods, and the like are pretty straightforwardly big forces that most of the time relegate earlier and smaller forces to de minimis or insubstantial status. Ordinary evening breezes, normal tidal movements, and other routine events do not overwhelm the causal contribution of wrongful action nearly so easily or so often.

More troublesoine are the cases of coincidence and of fully voluntary human action. We understand that both such types of items draw our explanatory interest and that the second of these two draws in addition our moral attention. But such pragmatic accounts of our judgments are irrelevant to the inetaphysics of causation. What is it about these types of interventions that overwhelms earlier causal contributions, relegating them to mere de minimus or insubstantial causes (Hart and Honorés "mere conditions")?

My own provisional answers to these last queries go like this. About coincidences, I share Hart and Honorés (and the case law's) intuition of nonresponsibility, but $I$ do not think this conclusion can be defended on causal grounds. Rather, it is a culpability discrimination doing the work of most of these cases. Where harm risked or intended occurs only because of extraordinary coincidence-such as a tree falling on a man only because of his earlier speeding - the harm as it happened is too far removed from the harm risked or intended for the actor to be held liable for it. There is a causal connection between the defendant's action and the harm that came about im most cases of coincidence, but not enough of the causal route was

233. The example is William Alston's. See his discussion of the beneficial uses of vagueness, in William Alston, Philosophy of Language (1964).

234. This is Richard Wright's example. See Wright, supra note 102, at 1795. 
within the contemplation of the actor to hold him responsible for the harm. ${ }^{235}$

About voluntary human actions intervening between defendant's act and the harm: doubtlessly the same culpability criterion can often explain the original actor's nonresponsibility. Whether there is also a causal discrimination at work here is inore troublesome. Prima facie, the choice to cause (or at least risk) the harm when made by the intervenor is a more substantial cause than the like choice nade by the original actor. This is true because such choices, in the abstract, are on a par, but the intervenor's choice is in greater spacio-teinporal proximity to the harm and is thus less diminished in its degree of causal contribution. Yet it is difficult to explam on causal grounds why choice itself is so significant. A negligent shot seemingly has as much causal power as an intentional shot, and even an involuntary movement can mimic exactly the physical characteristics of some voluntary movement. Absent soine brute mexplicability or libertarian freedom for human choices, it is hard to see how metaphysics can explain these legal discriminations.

\section{CONCLUSION}

As is probably evident from the last Part, ny own provisional bets on the metaphysics of causation are singularist and physicalist. Using such a metaphysics of force and energy, it is difficult to sustain some of the ordinary causal judgnients we make not only in law but also in sociology, economics, and other of the human sciences. It is tempting at this point to issue a John Searle-like statement: "This is as far as a philosopher need go; the rest is up to the physicists." ${ }^{1236}$ After all, philosopliy today is generally open to the insights of an advancing science in a way that would have shocked the Oxford ordinary language philosophy that lay behind Hart and Honoré's approach to causation. Yet from what has been done here, such an attitude is premature. Before he may pass off the project to the factgrubbers, a philosopher at least has to see how the facts could go so as to sustain some moral or legal conclusion. That is a point we have not yet reached about intervening causation.

235. How much of the causal route must be within the contemplation of the actor when he acts is a vague matter in morality, but this matches the vagueness in the ideas of coincidence and abnormality. On the general problem of fit between the harm done and the harm intended or risked, see MoorE, supra note 27 , at $459-76$.

236. Terry McDermott, No Limits Hinder UC Thinker, L.A. TImEs, Dec. 28, 1999, at A14 ("[C]onsciousness is solved as a philosophical problem and has become a matter of science. 'Let the brain stabbers figure out how it works ...."”). 
